\title{
Outeiro do Vale: sepulturas de Nogueira de Côta (Côta, Viseu)
}

\author{
Gertrudes Branco* \\ Marina Afonso Vieira**
}

\section{Resumo}

Neste texto dá-se conta dos resultados de uma pequena intervenção arqueológica motivada pela destruição parcial de uma sepultura paralelepipédica constituída por tegulae, em Julho de 2003. Os trabalhos decorreram um ano depois, no âmbito do projecto Da serra da Nave ao Vouga: paisagens humanas da Antiguidade Tardia à Alta Idade Média (Plano Nacional de Trabalhos Arqueológicos).

Os dados obtidos permitem pensar na existência de uma necrópole de transição, pois, para além da sepultura de tegulae, foi escavado outro sepulcro, estruturado com lajes de granito e detectado um possível terceiro enterramento. Apresenta-se ainda o contexto arqueológico relacionado, apontando-se para a existência de um habitat coetâneo das sepulturas e uma continuidade de ocupação durante a Alta Idade Média. O estudo desta necrópole e dos vestígios arqueológicos associados poderá proporcionar um importante contributo para uma melhor compreensão das necrópoles deste período, ainda tão pouco conhecidas.

\begin{abstract}
In this text the authors present the results of a small archaeological excavation compelled by the partial destruction of a tegulae made grave, in July 2003. These works took place one year later, associated to the project From Nave upper land to Vouga river: human landscapes from Late Antiquity to Early Middle Ages (National Plan of Archaeological Interventions). The gathered data points to the existence of a transition graveyard, for there is another burial, a granite lined grave, and possibly a third one. The related archaeological context is also presented: admittedly there is a contemporary settlement nearby and we can infer occupation continuity during the Early Middle Ages. The study of this burial ground and corresponding archaeological evidence may enlarge significantly our knowledge about this period funerary tradition, so little known at the present time.
\end{abstract}

\section{DESCOBERTA}

A Sepultura de Nogueira de Côta foi identificada em Julho de 2003, na sequência da abertura mecânica de uma vala, executada com o objectivo de impossibilitar a circulação de

\footnotetext{
* Instituto Português de Arqueologia.

** Centro de Estudios Arquelógicos das universidades de Coimbra e Porto. Bolseira de doutoramento da Fundação para a Ciência e a Tecnologia. Este texto foi elaborado no contexto dos seguintes projectos: Da Serra da Nave ao Vouga. Paisagens Humanas da Antiguidade Tardia à Alta
}

veículos motorizados pelo meio de um pinhal, propriedade do Sr. Joaquim Marques da Silva.

A Sepultura foi parcialmente afectada pelos trabalhos de escavação mecânica, que destruíram e colocaram a descoberto várias tegulae,

Idade Média (PNTA) e Formas de ocupación rural en el cuadrante Noroccidental de la Península Ibérica: transición y desarrollo entre las épocas Romano y Medieval (Universidad Autónoma de Madrid - HUM-2004-04010C02-02-HIST). 
possibilitando a sua identificação pelos trabalhadores que se encontravam no local.

A identificação dos vestígios deu de imediato origem à interrupção dos trabalhos, tendo sido contactada a arqueóloga da Extensão Territorial do Instituto Português de Arqueologia, em Viseu - Gertrudes Branco - que se deslocou ao local, na companhia do Presidente da Junta de Freguesia de Nogueira de Côta - Sr. Joaquim Polónio Lopes.

$\mathrm{Na}$ altura, devido à escassez de meios humanos e tempo disponível, a opção de salvaguarda passou pela cobertura da estrutura com geotêxtil e posterior aterro. Contudo, não foi feito um registo adequado do monumento, nem uma correcta avaliação do local, enquanto espaço arqueológico.

Com o objectivo de suprimir estas lacunas, e considerando o potencial científico do local, este foi inserido no projecto Da Serra da Nave ao Vouga, Paisagens humanas da Antiguidade Tardia à Alta Idade Média, da responsabilidade de Marina Vieira, ao abrigo do qual se realizou a escavação cujos resultados se reportam.

Os trabalhos decorreram de 5 a 10 de Julho de 2004, sob responsabilidade das signatárias e com a participação de João Carlos Alves Pires Teixeira, aluno de Arqueologia da Faculdade de
Letras da Universidade do Porto. Tivemos ainda a ajuda pontual de Fátima Beja e Costa e de Ana Barradas.

\section{O SÍTIO - IMPLANTAÇÃO}

O pinhal onde a sepultura foi encontrada fica na periferia da localidade de Nogueira de Côta, pertencente à freguesia de Côta, concelho e distrito de Viseu. Coordenadas UTM (ED 1950): 601417/4515901. A altitude é de cerca de $650 \mathrm{~m}$ (Carta Militar de Portugal 1:25 000, Fl. 167 de 1998).

O local onde foi identificada a sepultura de Nogueira de Côta (CNS 19224) está implantado na margem direita do rio Vouga, numa vertente suave de um outeiro, voltado a sul, sobranceiro a uma área aplanada a meio da encosta que desce para o rio. O local é bem irrigado por uma série de pequenas linhas de água que correm em direcção ao Vouga, que fica a um pouco menos de 1,5 Km. Em termos de ocupação do solo, existe um pinhal a envolver o sítio onde se encontra a sepultura, existindo outra mancha idêntica mais a sul; os campos cultivados (alguns denotando abandono) desenvolvem-se em socalcos até ao rio. A vinha e o milho são as culturas dominantes. Os solos são algo espessos e derivam da decomposição do granito base.

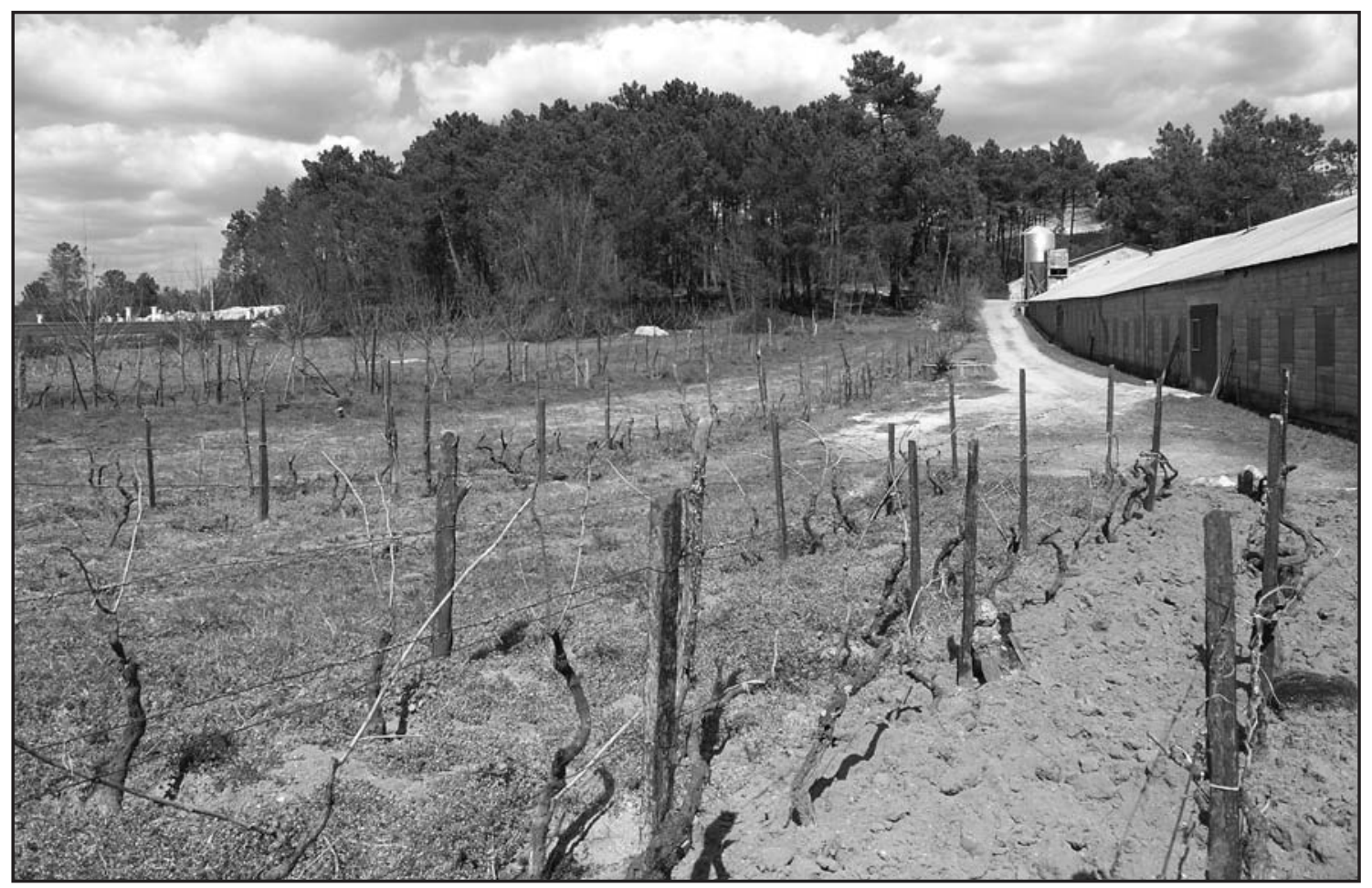

Fig. 1: Aspecto do local de implantação das sepulturas (no outeiro revestido de pinheiro), vista de sul. 


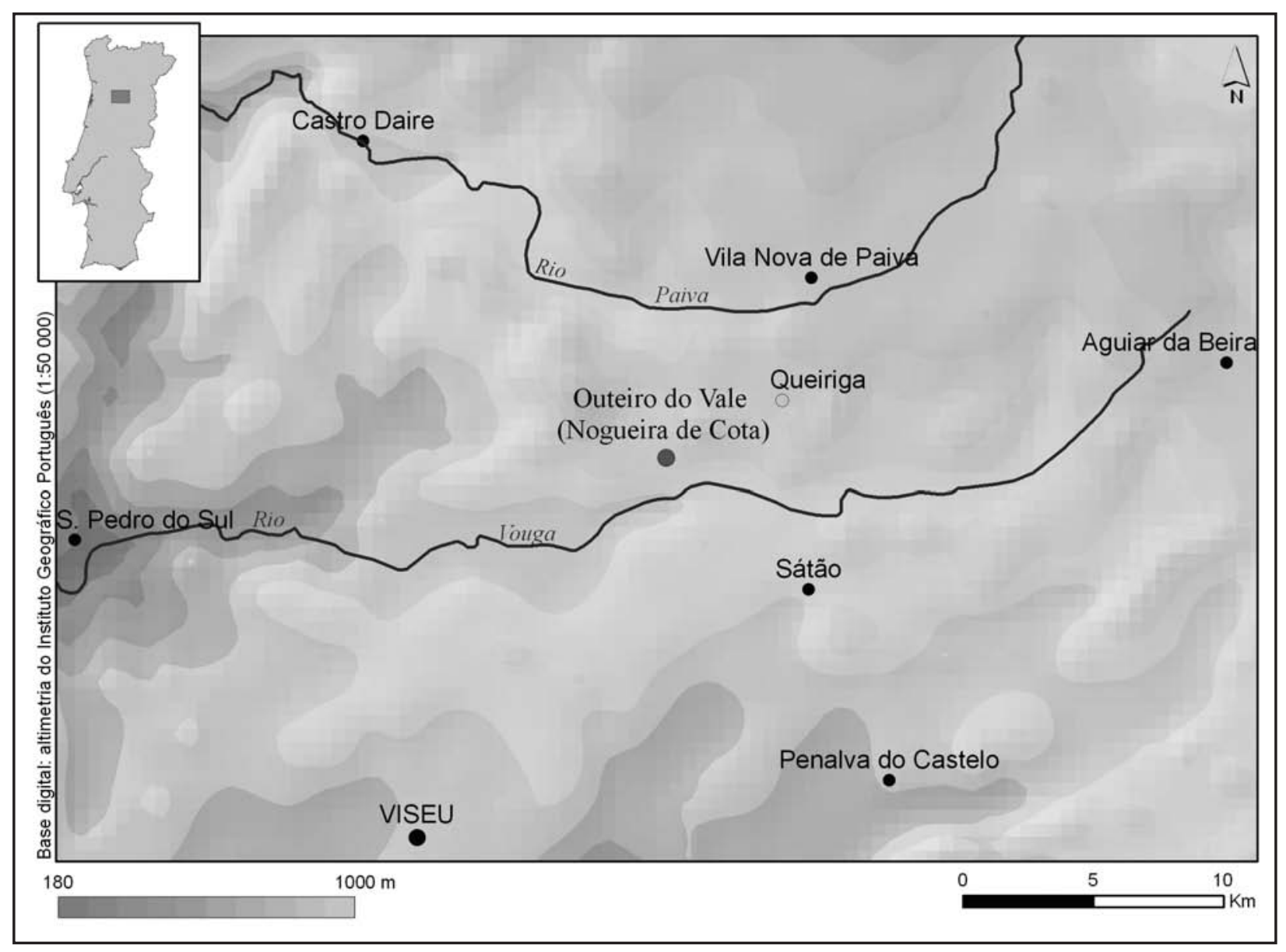

Fig. 2: Localização do sítio do Outeiro do Vale.

\section{INTERVENÇÃO}

A escavação surge na sequência de uma acção de destruição parcial, neste contexto foi nosso objectivo:

a) Avaliar e salvaguardar, através de registo científico, a Sepultura de Nogueira de Côta;

b) Perceber se estaríamos perante um enterramento isolado ou se este formaria parte de um cemitério;

c) Recolher elementos que nos permitissem aproximar da datação deste tipo de estrutura funerária.

\subsection{Metodologia}

Como já tivemos oportunidade de referir, após a sua identificação, a sepultura foi aterrada, não sendo visível, aquando do início dos nossos trabalhos, qualquer indício superficial que apontasse a sua localização exacta.

Em consequência, foi marcada uma primeira quadrícula de $2 \times 2 \mathrm{~m}$, cujos alargamentos, de forma a permitir enquadrar a duas sepulturas identificadas, totalizaram os $19 \mathrm{~m}^{2}$ (fig.3).

A quadriculagem foi implantada, aproximadamente, em sentido N-S (com um desvio de $10^{\circ}$ relativamente ao Norte magnético). Por questões de ordem técnica, não nos foi possível inserir a quadrícula na rede geodésica nacional, pelo que as cotas foram obtidas em relação a um ponto fixo, devidamente identificado, ao qual se deu o valor de 0 , sendo os valores todos negativos.

A escavação arqueológica decorreu seguindo os pressupostos metodológicos definidos por $\mathrm{P}$. Barker (1977) e E. Harris (1979). Assim, procedeuse à remoção das Unidades Estratigráficas [UE] pela ordem inversa à da sua deposição. Estas unidades foram registadas e descritas em ficha individual e inter-relacionadas, seguindo os pressupostos gerais da estratigrafia. A sucessão planimétrica foi registada fotográfica e graficamente (com recurso a fotografia analógica e digital, a escala gráfica utilizada foi a 1:20). 


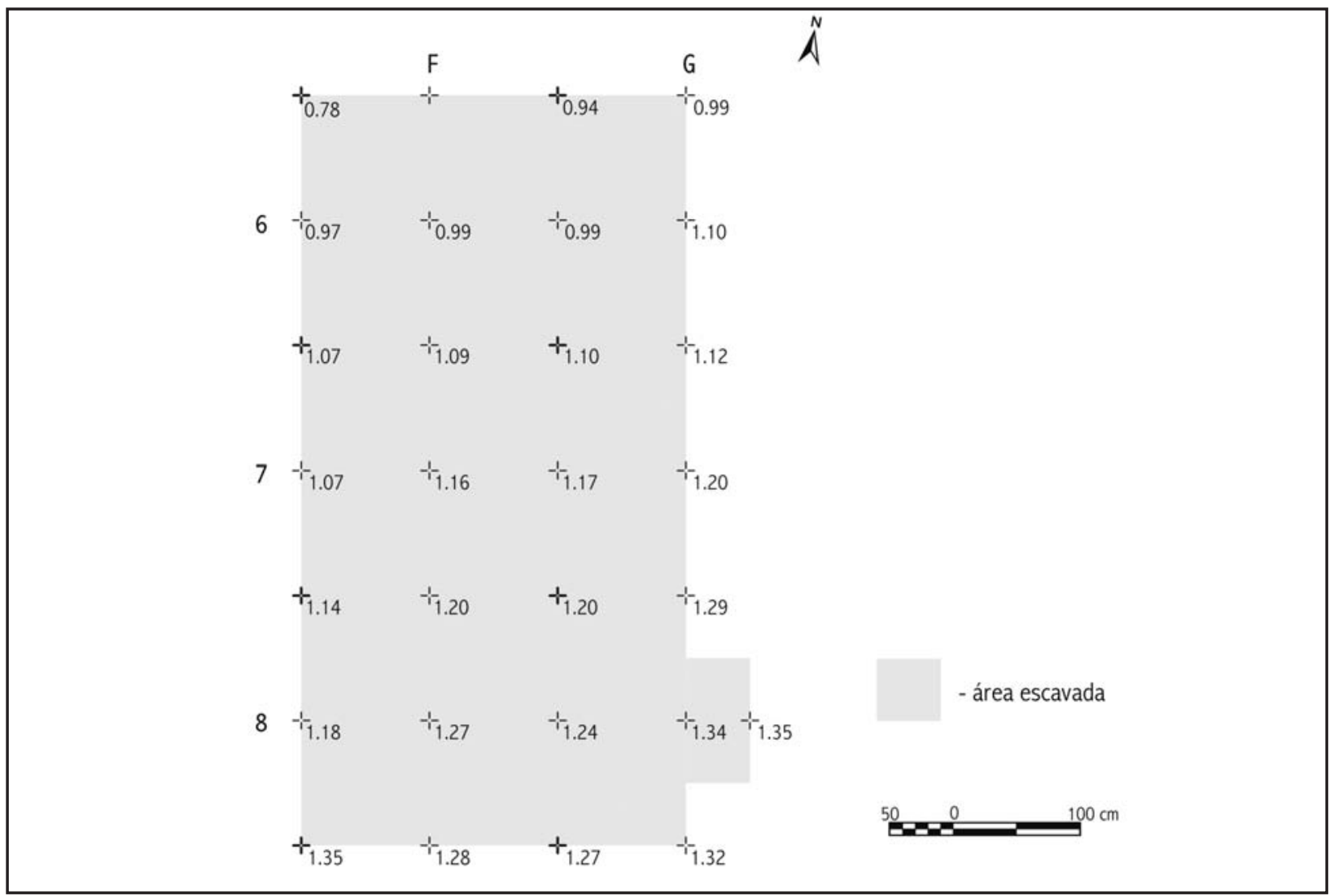

Fig. 3: Esquema de quadriculagem e topografia.

Todos os materiais arqueológicos recolhidos foram referenciados tridimensionalmente (X-Y-Z), em relação ao sistema de coordenadas implantado. Foram lavados, marcados e estudados, estando já entregues na Extensão Territorial de Viseu.

\subsection{Descrição e análise da estratigrafia}

No decurso da escavação foram detectadas 9 unidades estratigráficas, que passamos a descrever sumariamente.

UE 1 - Camada humosa, resultante da decomposição da caruma dos pinheiros e da vegetação superficial;

UE 2 - Camada heterogénea composta por revolvimento de saibro e terra vegetal, resulta da acção mecânica de abertura e entulhamento da vala;

UE 3 - Camada compacta, de tom castanho amarelado, recobre as sepulturas; é idêntica à camada geológica;

UE 4 - Sepultura constituída por 15 tegulae formando uma caixa rectangular. Parte da sepultura foi afectada pela abertura mecânica da vala, mas mantinha intacta a base e os topos. Algumas tegulae estavam fracturadas in situ pela pressão da terra;
UE 5 - Camada de terra, de tom castanho amarelado, com inclusão de saibro de granulometria grosseira e pouco frequente. Esta pouco se distingue da camada 3 , excepto pelo menor calibre das inclusões e pela menor compactação.

UE 6 - Camada de terra, de tom castanho amarelado, de compactação média;

UE 7 - Sepultura (incompleta) de lajes de granito, três laterais direitas, uma de cabeceira, uma lateral esquerda e três no leito. Possui fragmentos de tegulae no interior, que pertenceriam à cobertura;

UE 8 - Camada compacta, de tom castanho amarelado, é idêntica à camada geológica;

UE 9 - Laje e pequena pedra que se encontram no perfil poente da vala aberta por meios mecânicos. É possível que se trate de mais uma sepultura constituída por lajes, já que, apesar de ligeiramente deslocada pela acção destrutiva, apresenta a mesma orientação que os outros dois sepulcros. Só será possível confirmar esta hipótese numa posterior escavação. 


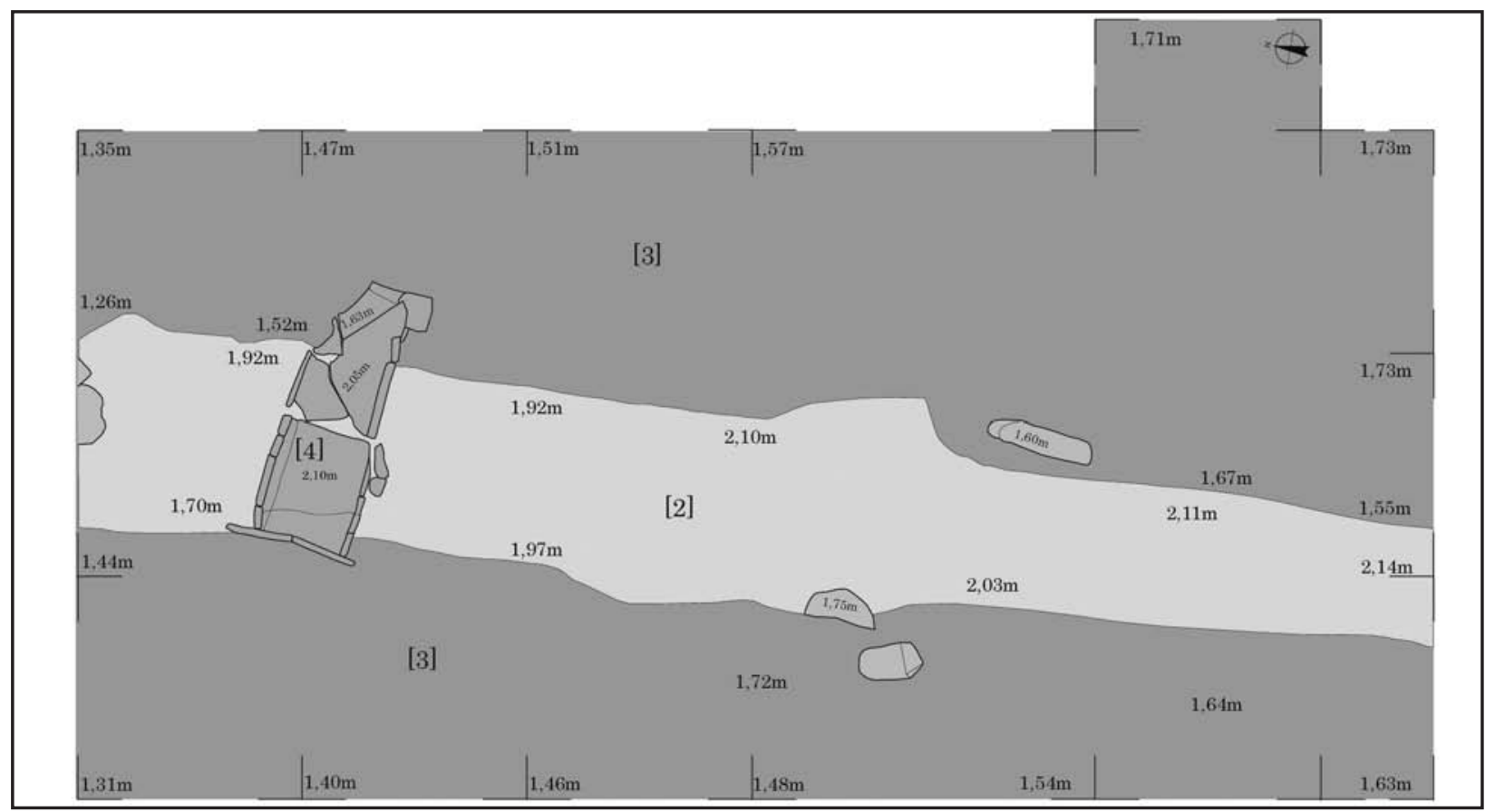

Fig. 4: Levantamento inicial em planta, sendo bem visível a vala, a sepultura 1 (UE 4) e os indícios das sepulturas 2 e 3 (UE 7 e UE 9).

A escavação empreendida revelou que a sepultura 1 estava efectivamente intacta até ao momento em que a máquina a destruiu parcialmente (vide Fig. 5, onde é notória a "marca" deixada pela destruição mecânica). Confirmou ainda que não continha espólio. A ausência de restos ósseos é de esperar em solos ácidos resultantes da degradação da rocha granítica.
Para além da sepultura 1, foi encontrada outra estrutura de inumação, a sepultura 2. Esta não foi afectada directamente pela abertura da vala, mas a laje do topo poente foi colocada a descoberto por esta acção. Este sepulcro foi parcialmente destruído em momento mais antigo, faltando a laje de cerre aos pés, duas lajes laterais do lado sul e a quase totalidade da cobertura. Este enterramento terá sido efectuado sensivelmente à
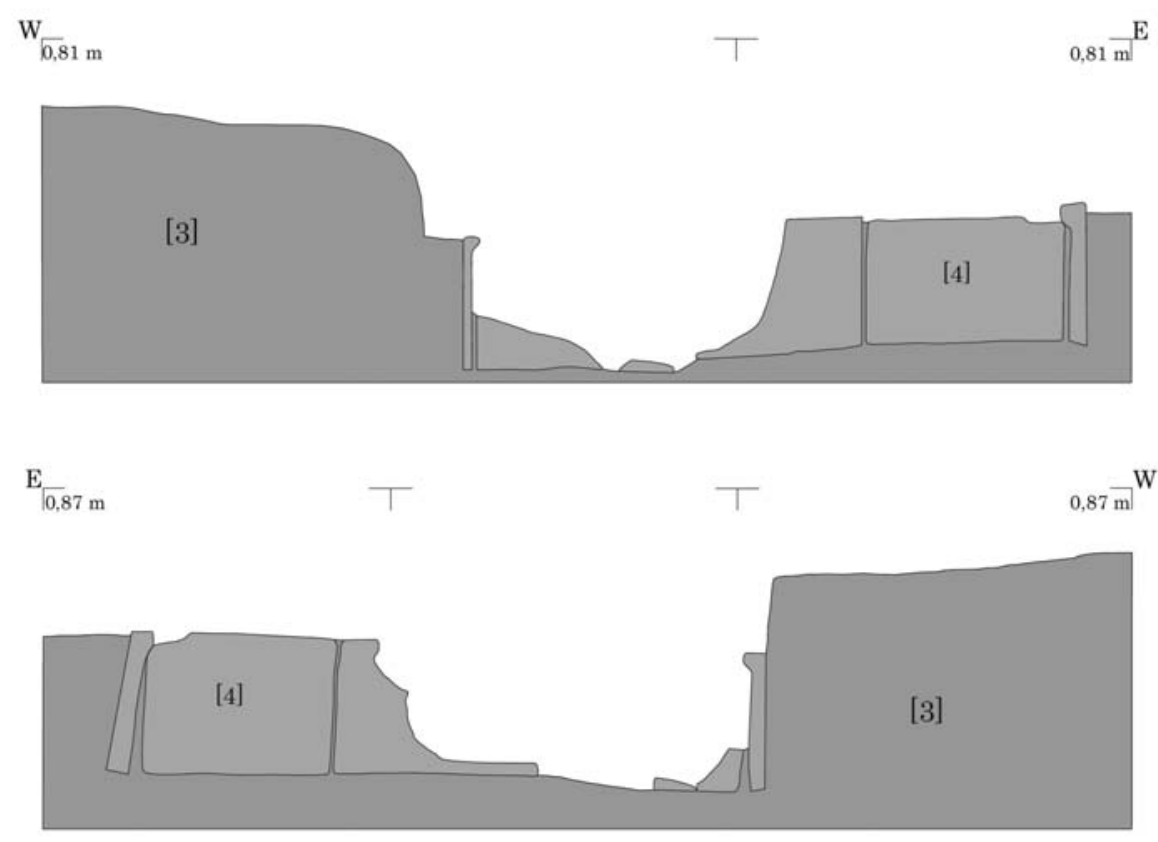

Fig. 5: Perfil da sepultura 1. 


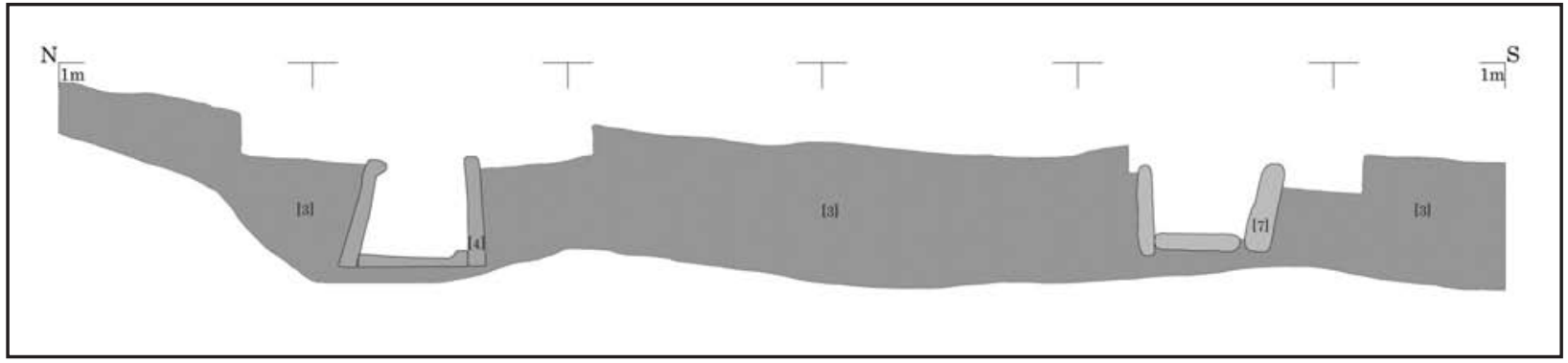

Fig. 6: Perfil Norte-Sul, mostrando as duas sepulturas.

mesma profundidade que a sepultura 1 (vide fig.6), mas como o terreno apresenta pendente, de norte para sul, esta última tem menos sedimentos a cobri-la, o que poderá ter facilitado a sua destruição.

No corte deixado pela acção mecânica, no lado poente, ficaram visíveis duas pedras graníticas (UE 9), uma delas claramente afeiçoada, que poderão corresponder a uma outra sepultura de lajes (vide Fig. 4). Apesar de terem sido ligeiramente deslocadas da sua posição original apresentam a mesma orientação que os outros dois sepulcros.

É de notar que praticamente todas as unidades apresentam uma coloração muito semelhante, se exceptuarmos a UE 1 que - como se espera numa camada humosa -, apresentava um tom castanho mais escuro. Esta situação não dificultou muito o processo de interpretação, mas poderá ter obviado a identificação de valas de fundação das sepulturas, embora sejamos da opinião que a compactação do solo base permite uma simples aposição do material de construção na vala aberta. Portanto as tégulas ou lajes poderão ter assentado na fossa escavada, directamente sobre o solo base.

A UE 3 corresponde à terra que foi escavada aquando da abertura da vala para proceder à construção das sepulturas e que terá sido posteriormente depositada sobre as mesmas, sem que seja possível fazer distinção morfológica entre este sedimento e aquele que constitui o solo base.

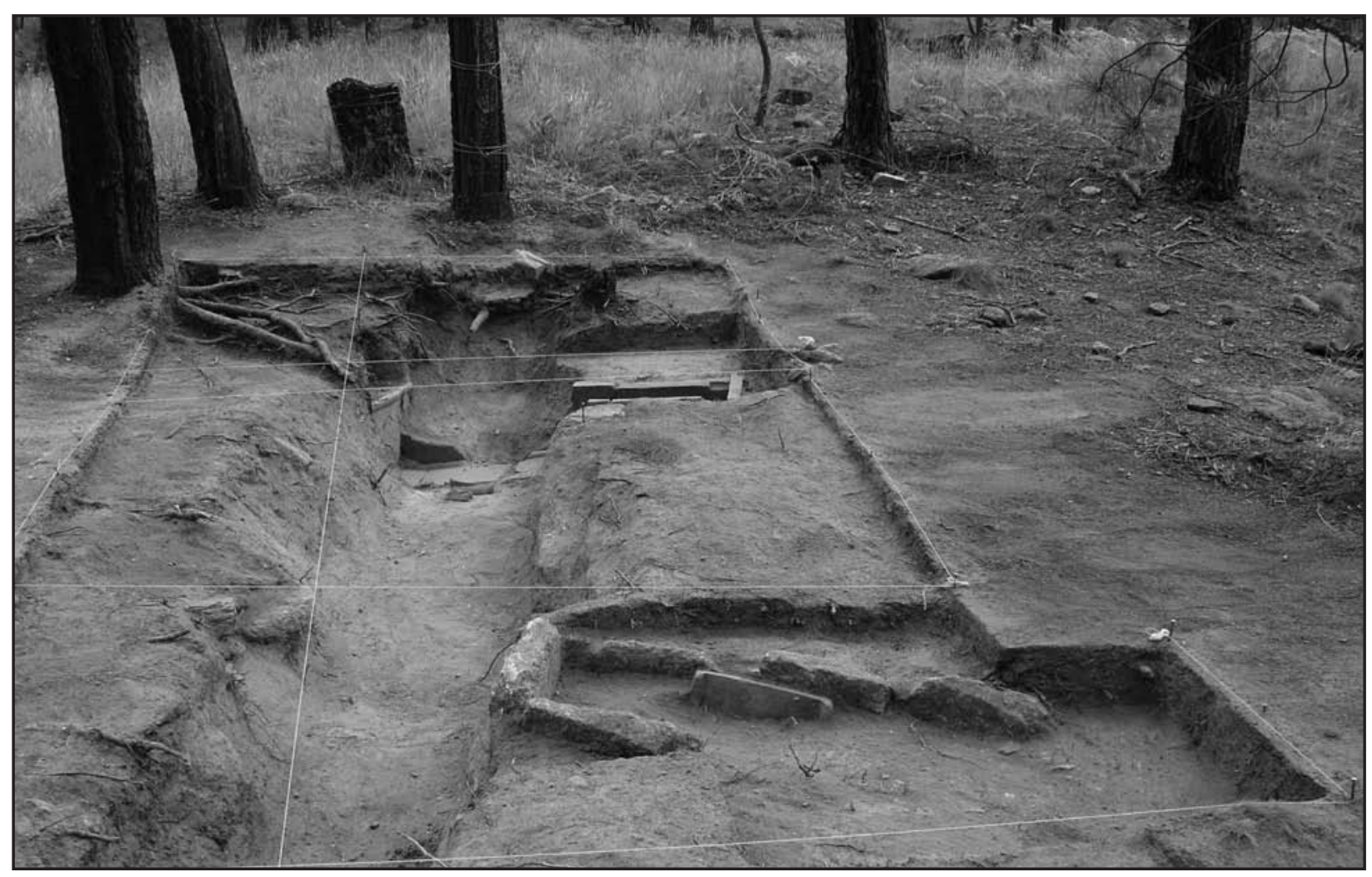

Fig. 7: Vista de sul das duas sepulturas em decurso de escavação. Em primeiro plano a sepultura 2. 
Pelo estado de fractura da tegula que cobriria a sepultura 2, completamente abatida para o interior (vide Fig. 7, em primeiro plano, o aparecimento dos fragmentos), será de supor a sua colocação directamente sobre a caixa tumular, sem que tenha sido colocada terra sobre o cadáver. A sepultura 1, de que se conservaram duas tegulae da cobertura (do lado nascente, vide Fig. 8), apresenta uma situação diferente: se bem que muito fracturadas pela pressão do solo, não se encontram abatidas para o interior e repousam sobre a UE $5^{1}$. Não foram encontrados vestígios de um ataúde no seu interior, pelo que se impõe a busca de outra interpretação. A nosso ver existem pelo menos duas alternativas: ou existia uma estrutura em tábuas de madeira não ligadas entre si (daí a inexistência de pregos), que se poderia resumir à cobertura, aguentando a pressão da terra até que a infiltração da mesma acabasse por sustentar a estrutura cerâmica, ou então terá sido colocada terra sobre o defunto. Qualquer das hipóteses é difícil de comprovar quando os materiais perecíveis não se conservaram e é impossível fazer um exame à

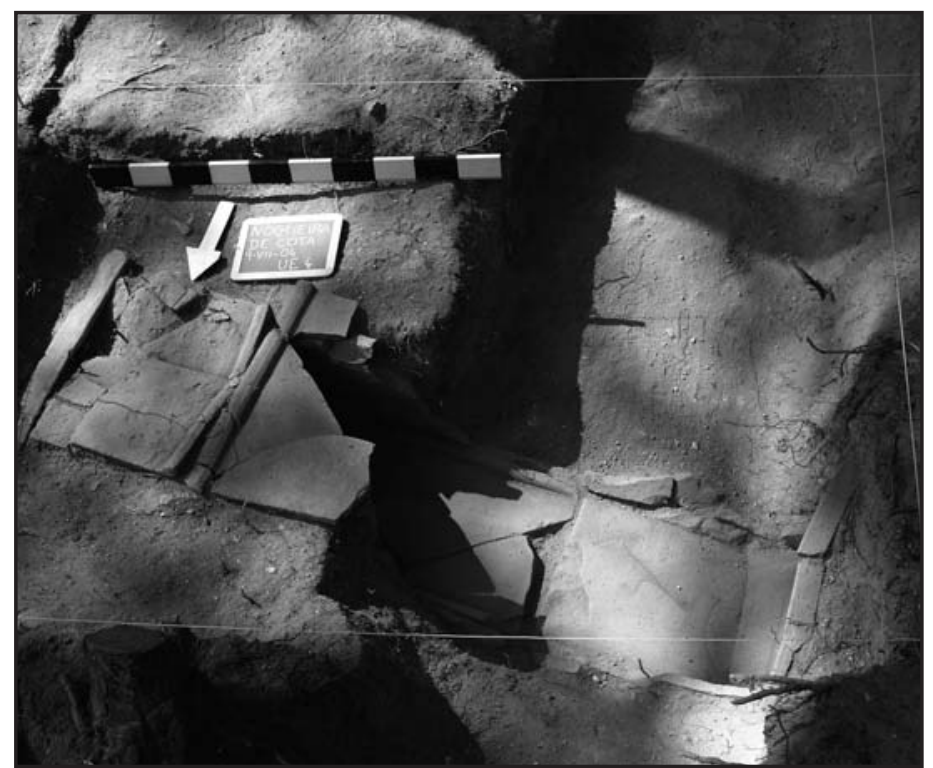

Fig. 8: Aspecto da sepultura 1, sendo visível o que restou da cobertura.

forma como o corpo se decompôs.

Partindo desta premissa, a UE 6 será constituída pelas terras que se foram infiltrando na cavidade sepulcral após a deposição do defunto e o colapso da cobertura. A UE 5 será de origem idêntica, ou foi colocada directamente

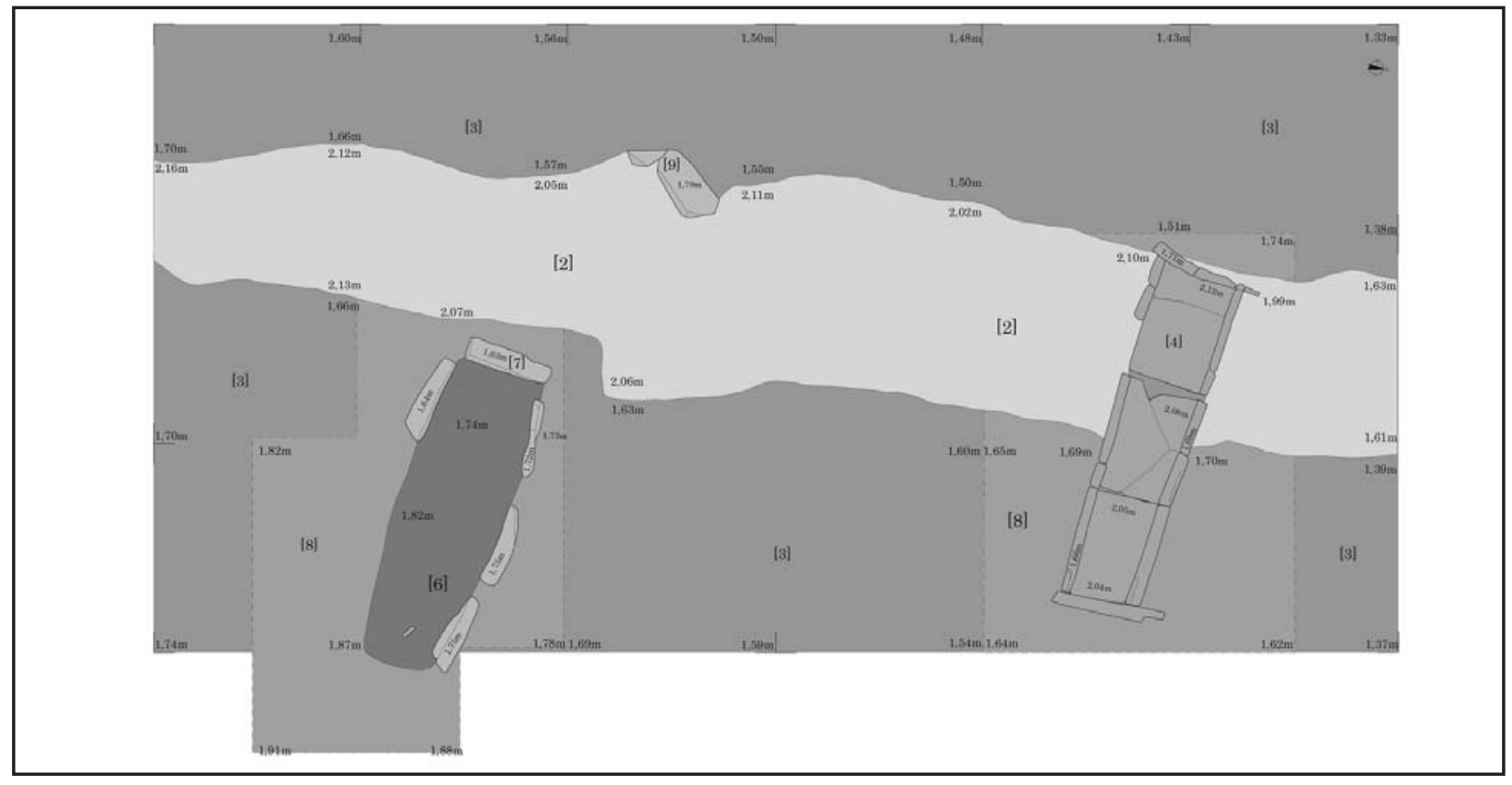

Fig. 9: As sepulturas em planta.

1 Atente-se que a tegula que se encontra incompleta (a segunda a contar de nascente) foi partida pela máquina, pois apresentava fracturas recentes. 
sobre o corpo. A primeira hipótese parece ser sustentada pelo facto destas unidades estratigráficas (5 e 6) serem constituídas por um sedimento idêntico ao da UE 3, mas menos compacto e com menos inclusões, embora quando aparecem sejam idênticas às desta.

Pelo que nos foi dado observar e atendendo à distinta tipologia, as duas sepulturas não serão contemporâneas, a 2 será posterior à 1 , mas também não terão uma diferença cronológica muito grande, o que é sugerido pelas idênticas profundidade de enterramento, planta, orientação e ausência de mobiliário fúnebre conservado.

A detecção de uma possível terceira sepultura [UE 9] aponta no sentido de estarmos em presença de uma necrópole, até porque é neste contexto que surgem vulgarmente este tipo de sepulturas.

Não nos foi possível apurar se as sepulturas estavam assinaladas à superfície devido aos processo pós-deposicionais. O solo que cobria as sepulturas terá sido revolvido pela actividade agrícola, mais tarde afectado pela plantação de pinheiro bravo, para além de que terá existido também alguma erosão devida à pendente, notada sobretudo pela pequena profundidade do solo sobre a sepultura 2 .

No que toca à cronologia, não se obtiveram dados que permitissem aclarar o momento de construção das sepulturas. Esta é, de resto, uma das grandes dificuldades relacionadas com a interpretação deste tipo de estruturas, que é comum quando não existe espólio a elas associado e que se intensifica com a a ausência de ossadas que inviabiliza o recurso aos meios de datação absoluta.

Os materiais empregues na construção da sepultura 1 e na cobertura da sepultura 2 também não constituem indicadores cronológicos, uma vez que - por um lado - as tegulae poderão ser reutilizações de construções em ruínas e - por outro - hoje é genericamente aceite que terão continuado a ser fabricadas durante a Alta Idade Média.

\section{As Sepulturas}

A Sepultura 1 é de forma alongada, apresentando secção quadrada e plano rectangular. Está orientada Oeste-Este $\left(260^{\circ}\right)$. As três tégulas que constituem o leito e cada um dos laterais foram colocadas em comprimento, as primeiras colocadas com o rebordo para cima e as segundas com o rebordo para fora. A cobertura, pelo que nos foi dado conhecer pelas duas tegulae que ficaram in situ após a destruição, foi feita com este material colocado transversalmente (em largura), o que implica o uso de quatro tegulae (mais uma do que no fundo e cada lateral). Em cada um dos topos foi colocada uma tegula com o rebordo voltado para o interior. As tegulae estariam inteiras aquando da construção do sepulcro, sendo de imputar à pressão da terra e à acção destrutiva contemporânea as fracturas detectadas nas peças in situ. Das oito tegulae completas encontradas na posição original, seis apresentam marcas feitas antes da cozedura. Estas linhas digitadas parecem delinear algo semelhante a uma letra 'd' maiúscula (vide Fig. 11), de formatos muito

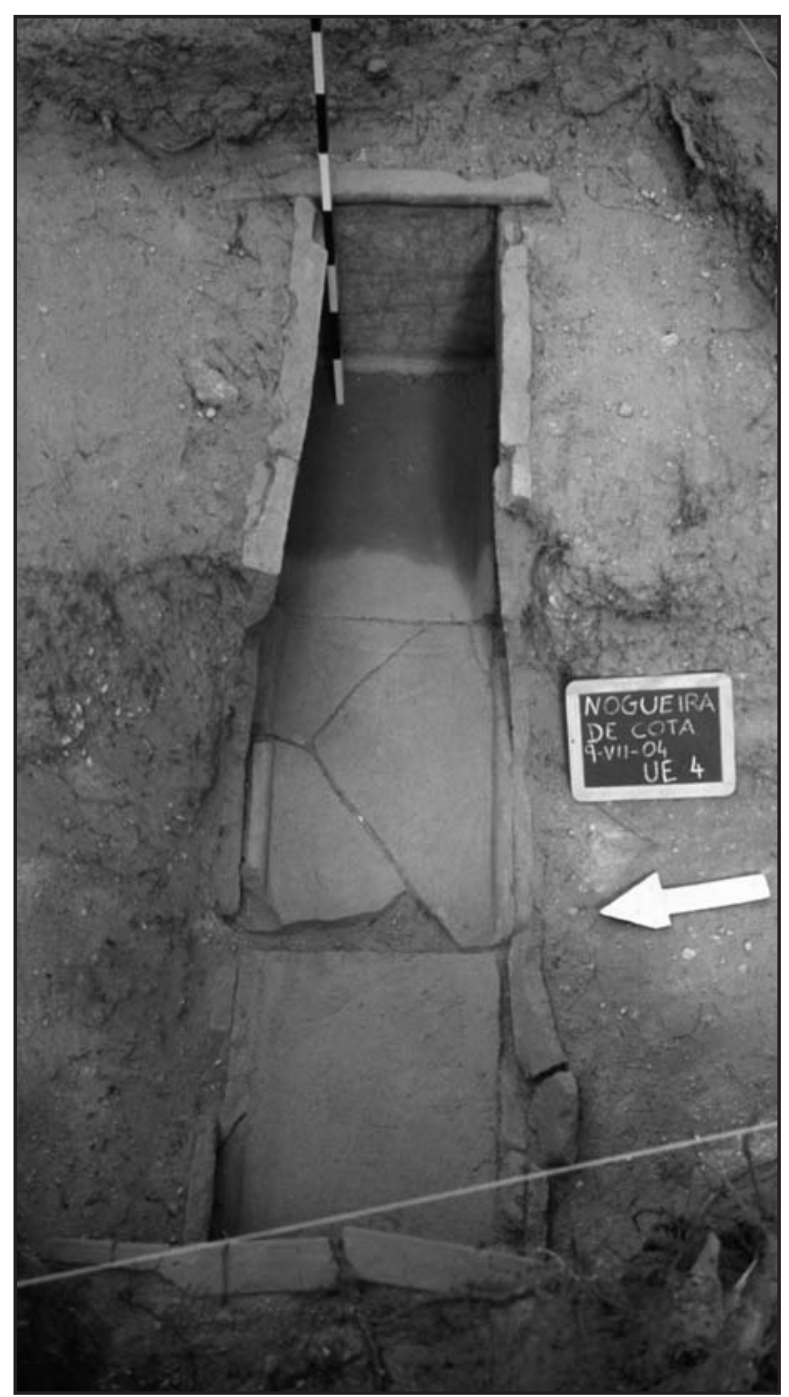

Fig. 10: Sepultura 1 depois de retirada a UE 5. 


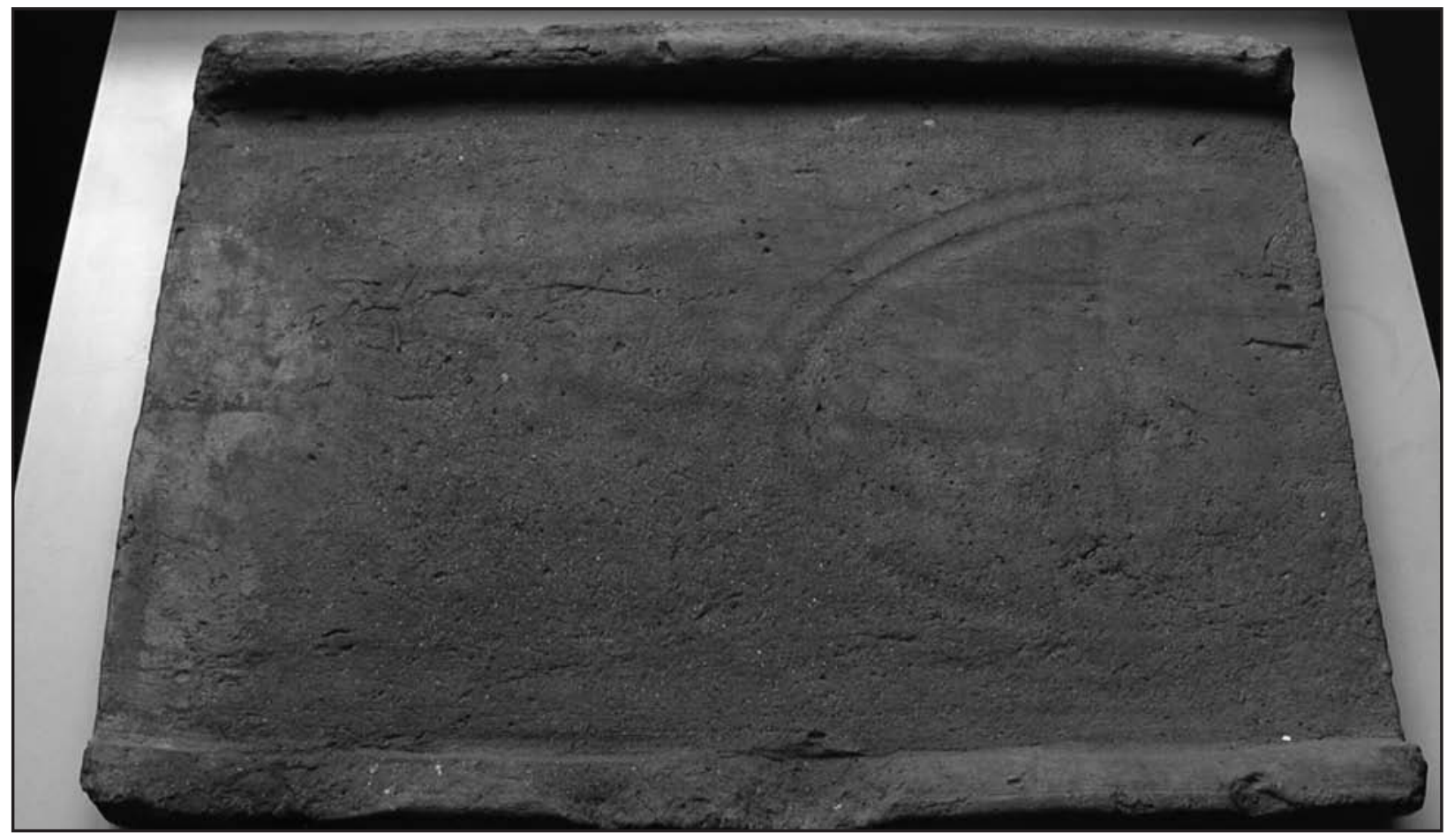

Fig. 11: Tegula do leito, extremo nascente.

diferentes entre $\mathrm{si}^{2}$. A primeira tegula da cobertura do lado nascente $(\mathrm{M})$, para além dessa marca ostenta várias pegadas de um pequeno ungulado. Tudo características que se encontram nas vulgares peças de cobertura de um telhado de tipo romano. Registe-se que estes materiais de cobertura apresentam acabamento superficial, coloração e constituintes das pastas heterogéneos, o que será consentâneo com a interpretação, mais ou menos generalizada para este tipo de sepulcros, que aponta para a reutilização de materiais.

\begin{tabular}{|c|c|c|c|c|c|c|c|c|c|c|c|}
\hline \multirow{2}{*}{$\begin{array}{c}\text { Referência }^{3} \\
\text { Tegula }[\mathrm{A}]\end{array}$} & \multirow{2}{*}{$\begin{array}{l}\text { Localização } \\
\text { topo nascente }\end{array}$} & \multicolumn{2}{|c|}{ Comp. } & \multicolumn{2}{|c|}{ Largura } & \multicolumn{2}{|c|}{ Espes. } & \multicolumn{2}{|c|}{ Larg.Reb. } & \multicolumn{2}{|c|}{ Alt. Reb. } \\
\hline & & 56,3 & 56,5 & 41,5 & 40,7 & 3,4 & 3,7 & 4 & 3,5 & 5,5 & 4,9 \\
\hline Tegula $[\mathrm{B}]$ & $\begin{array}{c}\text { tegula leito, extrem. } \\
\text { nascente }\end{array}$ & 57,5 & 57,5 & 42 & 42,5 & 2,4 & 2,9 & 4,7 & 4,4 & 5 & - \\
\hline Tegula $[\mathrm{C}]$ & tegula central do leito & 55,5 & - & 41 & 41,5 & 3 & 2,8 & 3,2 & 3 & 6 & 5 \\
\hline $\begin{array}{c}\text { Tegula }[\mathrm{E}] \\
\text { fragmentada }\end{array}$ & topo poente & 55,5 & - & - & - & 2,8 & 2,9 & 4,5 & - & 4,5 & - \\
\hline Tegula $[\mathbf{F}]$ & $\begin{array}{l}\text { lateral sul, extrem. } \\
\text { nascente }\end{array}$ & 55,9 & 56 & 42 & 42,5 & 3 & 3 & 4,5 & 4 & 5,3 & 4,9 \\
\hline Tegula $[\mathrm{H}]$ & $\begin{array}{l}\text { lateral sul, extrem. } \\
\text { nascente }\end{array}$ & 55,5 & 56 & 42,2 & 42,2 & 3,3 & 3,4 & 4 & 3,5 & 6 & 5,5 \\
\hline $\begin{array}{c}\text { Tegula }[\mathrm{M}] \\
\text { fragmentada }\end{array}$ & $\begin{array}{l}\text { tegula da cobertura, } \\
\text { extrem. nascente }\end{array}$ & - & - & - & - & 2,5 & 2,8 & 4 & - & 5,5 & - \\
\hline
\end{tabular}

Quadro 1: Dimensões das tegulae encontradas completas in situ.

2 Não sabemos se teria algum significado funcional, como o de indicar a posição da tegula no telhado. Curioso é que nem todas apresentavam o típico encaixe da zona de sobreposição (como é o caso da apresentada na Fig. 11).

3 Foram atribuídas letras às tegulae, de $\mathrm{A}$ a $\mathrm{P}$, de poente para nascente. 


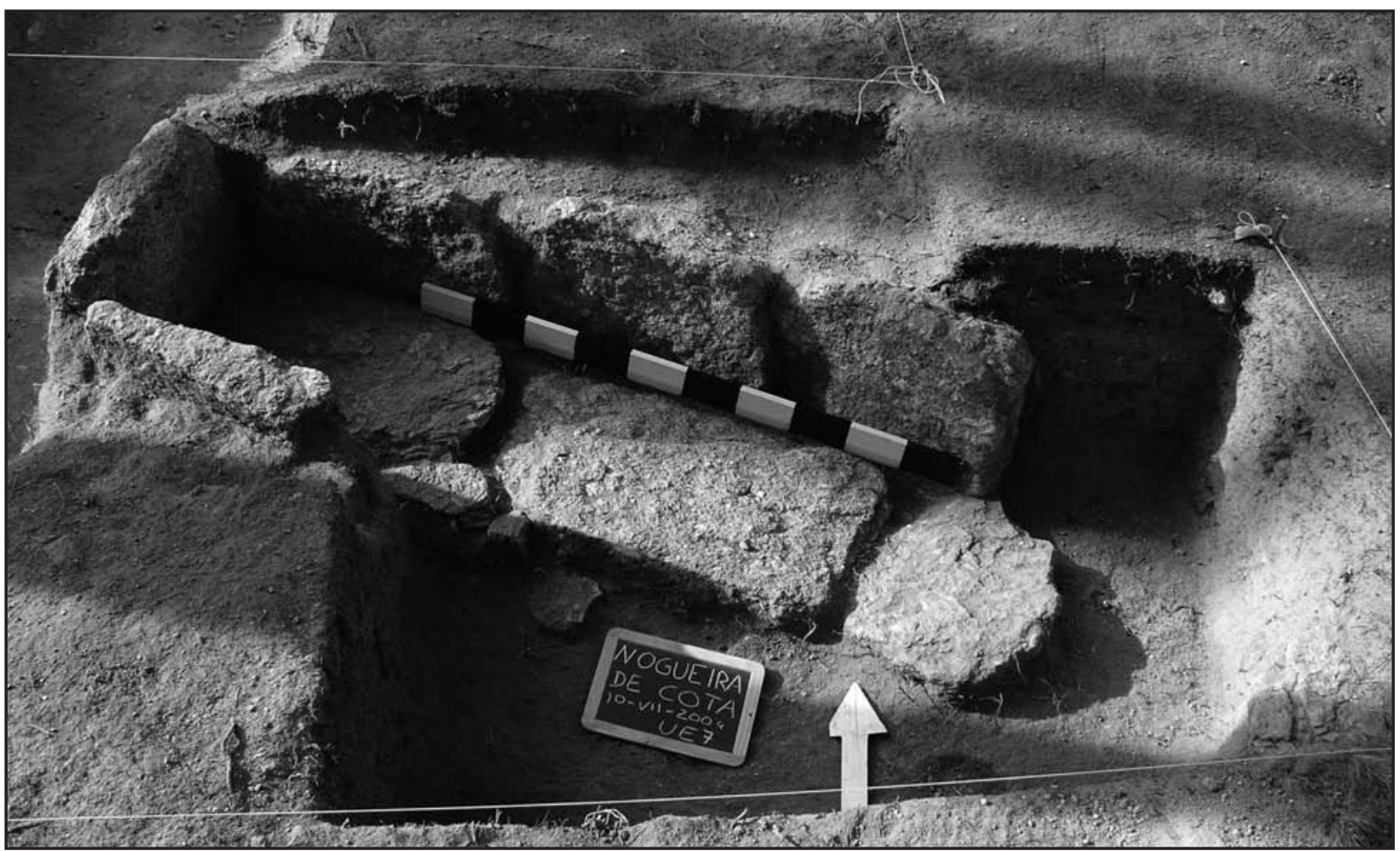

Fig. 12: Aspecto da sepultura 2, vista de sul.

A Sepultura 2: seria uma cavidade rectangular, constituída por lajes de granito de forma sub-rectangular. Está orientada OesteEste $\left(255^{\circ}\right)$. O leito é constituído por três lajes dispostas em comprimento e por duas pequenas pedras que colmatam o interstício entre a primeira e a segunda laje (a partir do lado poente). Só um dos laterais se encontra preservado, o do lado norte, formado por três lajes, do lateral sul resta uma laje; estão colocadas em comprimento. Só nos resta o topo de poente, uma laje única disposta em comprimento (embora metricamente seja a laje que mais se aproxima da forma quadrangular). A cobertura desapareceu na sua quase totalidade, restando apenas uma tegula incompleta fracturada ao centro e abatida para o interior da cavidade sepulcral. Estava disposta em largura (tal como as tegulae de cobertura da sepultura 1). Do ponto de vista morfológico, apresenta proximidade com a sepultura 1 , pois a sua planta é semelhante, embora o efeito paralelepipédico não seja tão perfeito. A técnica empregue também não foi muito diferente, embora os materiais o sejam. A profundidade dos enterramentos também não difere muito.

\begin{tabular}{|l|c|c|}
\cline { 2 - 3 } \multicolumn{1}{l|}{} & Sepultura 1 & Sepultura $\mathbf{2}^{4}$ \\
\hline Comprimento máximo & $1,90 \mathrm{~m}^{5}$ & $1,76 \mathrm{~m}$ \\
\hline Comprimento do leito & $1,72 \mathrm{~m}$ & - \\
\hline Largura máxima & $0,58 \mathrm{~m}$ & $0,50 \mathrm{~m}$ \\
\hline Largura máxima (do leito) & $0,44 \mathrm{~m}$ & - \\
\hline Profundidade (da cavidade) & $0,38 \mathrm{~m}$ & $0,28 \mathrm{~m}$ \\
\hline
\end{tabular}

Quadro 2: Dimensões das sepulturas. 


\section{ENQUAdRAmento ARQUeOlógico}

\subsection{O sítio e a sua envolvente}

A interpretação das sepulturas de Outeiro do Vale só é possível tendo em conta o contexto arqueológico em que se inserem. Com efeito, há outros vestígios arqueológicos que, pela sua proximidade e natureza, poderão estar relacionados (cartografados no mapa da Fig. 13). Comecemos pelos testemunhos funerários.

A primeira referência que encontramos ao sítio conhecido por 'Escoiral', é feita por Celtibero Lusitano. Trata-se de notas soltas, fruto das diversas visitas que o autor foi efectuando ao local ${ }^{6}$, nelas dá notícia de duas "sepulturas antropomórficas" e de uma "urna incompleta" (1991, p. 93, 117). Alguns anos mais tarde, encontramos a referência de I. Vaz que, na sua descrição do sítio, escreve: "Cerâmicas domésticas e de construção variadas, mós e grande quantidade de escórias. Há ainda túmulo monolítico, não antropomórfico" (Vaz, 1997, p. 131).

No local confirmámos estas notícias e verificámos a existência de mais uma sepultura rupestre. Temos, portanto, um pequeno núcleo de três sepulturas não antropomórficas, escavadas no granito, a pouco mais de 200 metros a sul da área escavada. A primeira encontra-se muito mutilada, mas possuiria um contorno ovalado, encontra-se num afloramento ao nível do solo actual. As outras duas estão a poucos metros uma da outra, num pequeno outeiro formado por grandes rochas graníticas, sobressaindo na paisagem. Em volta das sepulturas os campos não se encontram actualmente cultivados.

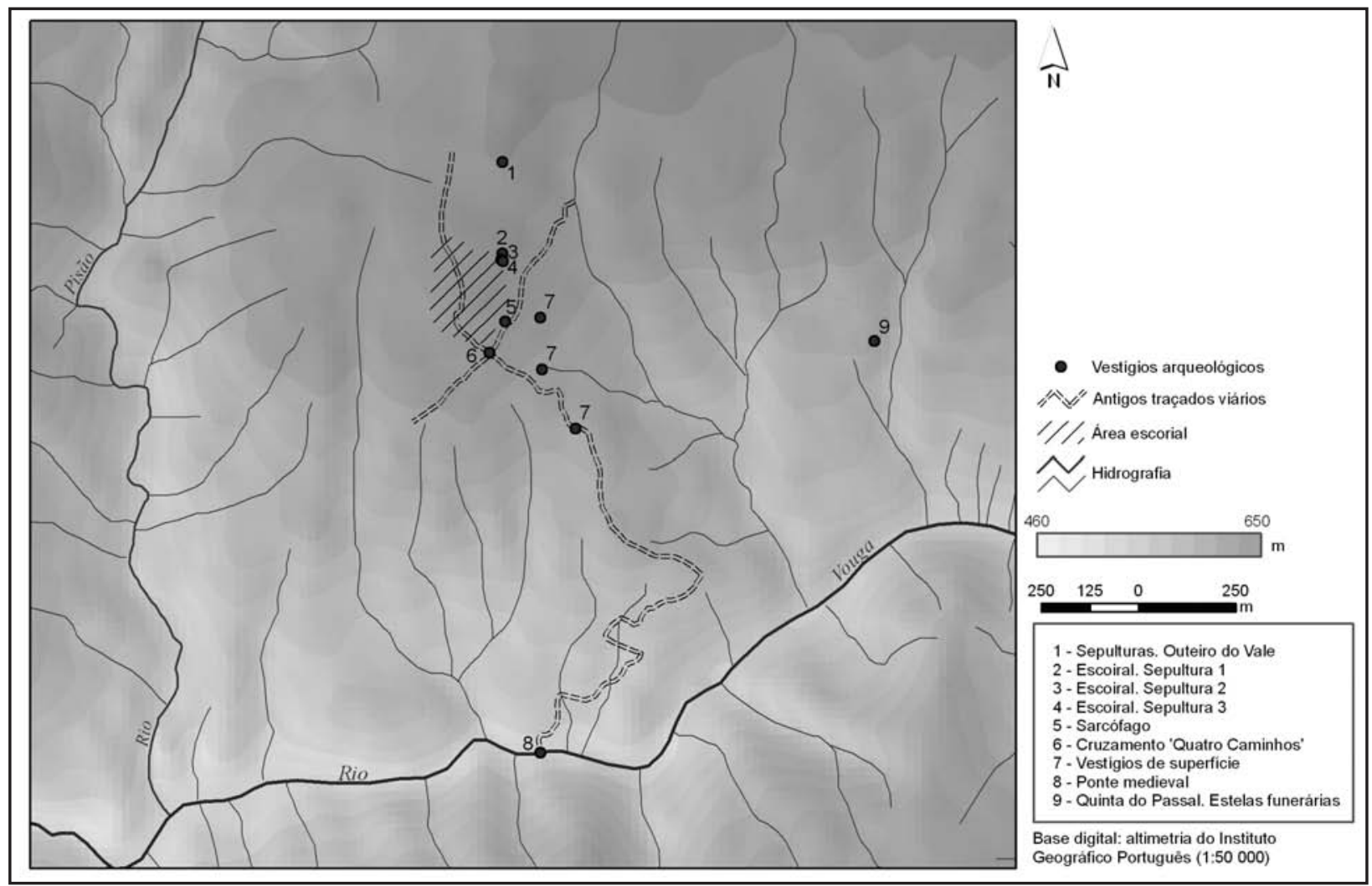

Fig. 13: Contextualização arqueológica do sítio do Outeiro do Vale.

4 As dimensões correspondem aos máximos verificados, isto é, deverão ser lidos como indicativos das medidas que teria a sepultura completa.

5 Esta medida, tão diferente da do leito, deve-se à deslocação das tegulae devido à acções pós-deposicionais. Antes destas teria cerca de 1,80 m. Esta alteração é visível sobretudo na área poente do topo da sepultura. Pensamos que se deverá às raízes de árvores que terão envolvido aquela zona da estrutura, provocando a sua deslocação e abatimento. Veja-se na
Fig. 5 o abatimento no perfil e na Fig. 9 a fractura e consequente deformação da tegula do topo poente.

$6 \mathrm{O}$ autor foi publicando pequenas notícias na revista Beira Alta, com o pseudónimo Celtiberus Lusitanus, que posteriormente foram reunidas num livro, edição de 1991, que nos serve aqui de referência. Trata-se de um curioso, que inclusivamente classificou as sepulturas como "antropomórficas" quando elas nem sequer mostram qualquer tendência nesse sentido. 


\begin{tabular}{|c|c|c|c|}
\hline $\mathrm{N}^{\circ}$ dentro do grupo 7 & 1 & 2 & 2 \\
\hline Situação da sepultura & em grupos de $2 / 3$ & em grupos de $2 / 3$ & em grupos de $2 / 3$ \\
\hline Situação em Necrópole & isolada & em grupo de $2 / 3$ & em grupo de $2 / 3$ \\
\hline Conservação & fracturada & inteira sem tampa & inteira sem tampa \\
\hline Orientação em graus & 280 & 30 & 325 \\
\hline Técnica construtiva & totalmente escavada na rocha (?) & totalmente escavada na rocha & totalmente escavada na rocha \\
\hline Tipologia geral & não antropomórfica & não antropomórfica & não antropomórfica \\
\hline Tipologia A & ovalada & sub-rectangular & sub-trapezoidal \\
\hline Tipologia B & - & - & - \\
\hline Cabeceira & - & - & - \\
\hline Plano da cabeceira & cabeceira e leito no mesmo plano & cabeceira e leito no mesmo plano & cabeceira e leito no mesmo plano \\
\hline Plano dos pés & leito e pés no mesmo plano (?) & leito e pés no mesmo plano & leito e pés no mesmo plano \\
\hline Comprimento & 1,70 & 1,68 & 1,73 \\
\hline Comprimento leito & 0 & 1,65 & 1,70 \\
\hline Largura máxima & 0,52 & 0,51 & 0,47 \\
\hline Largura nos ombros & 0 & 0,51 & 0,47 \\
\hline Profundidade máxima & 0,42 & 0,39 & 0,38 \\
\hline Comprimento cabeceira & - & - & - \\
\hline Largura cabeceira & - & - & - \\
\hline Rebordo & 0 & - & - \\
\hline Rebordo tipo & - & - & - \\
\hline Secçāo longitudinal & 0 & assimétrico, plano inclinado & assimétrico, plano inclinado \\
\hline Secção transversal & 0 & fundo irregular, lados assimétricos & fundo côncavo, lados assimétricos \\
\hline Implantação & meia encosta & outeiro & outeiro \\
\hline Implantação especifica & afloramento & afloramento & afloramento \\
\hline Associação a templo & 0 & 0 & 0 \\
\hline $\begin{array}{l}\text { Proximidade de traçados } \\
\text { viários antigos }\end{array}$ & romano/medieval & romano/medieval & romano/medieval \\
\hline \multirow{2}{*}{$\begin{array}{lc}\text { Coordenadas UTM } & \text { X } \\
\text { ED } 1950 & \text { Y }\end{array}$} & 0601421 & 0601414 & 0601419 \\
\hline & 4515671 & 4515650 & 4515645 \\
\hline
\end{tabular}

(?) = indefinição devido à fractura; " 0 " = indeterminado; "- " = não existe, não se aplica.

Quadro 3: Descritivo das sepulturas rupestres ${ }^{8}$.

Para além dos sepulcros rupestres há também um sarcófago que, infelizmente, foi deslocado do local de achado, encontrando-se hoje a sul das sepulturas rupestres, sobre uma aglomeração de grandes pedras (algumas das quais aparelhadas, sendo possível que sejam provenientes de um contexto arqueológico).

7 As sepulturas foram numeradas de norte para sul.

8 Acerca da metodologia do registo apresentado ver Vieira, 2006.

9 Este sarcófago é semelhante aos do sítio de S. Martinho de
Trata-se de um sepulcro monolítico, fracturado na zona direita da cabeceira, de configuração sub-trapezoidal. O exterior do arcaz denuncia a forma interior. Esta morfologia é de cariz arcaico, podendo ter uma cronologia próxima da das sepulturas rupestres já descritas ${ }^{9}$.

Almoneixe (cf. Vieira, 2004, p. 77, 143-144). Acerca da cronologia cf. Barroca, 1987, p. 180. 


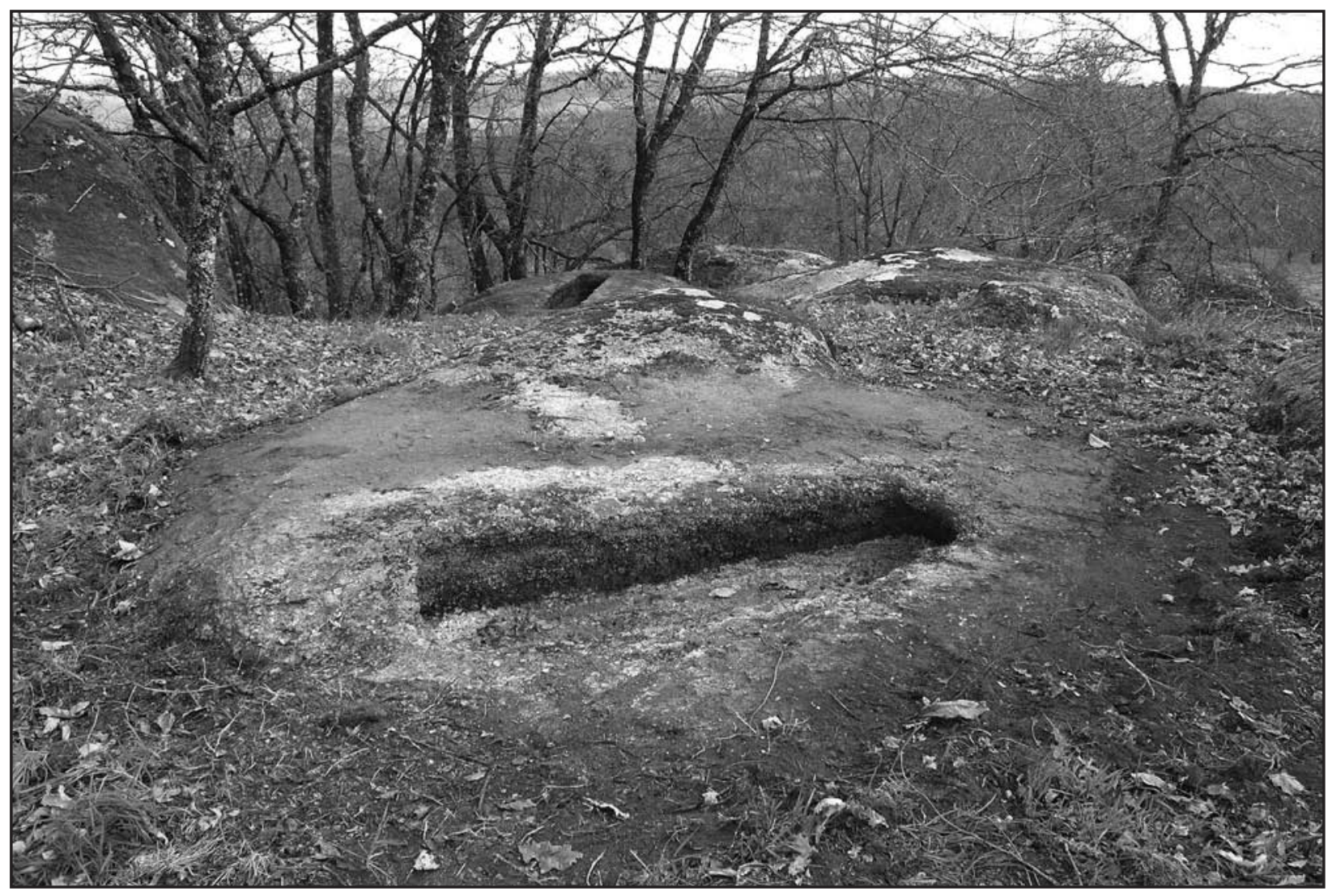

Fig. 14: Escoiral, aspecto da implantação das sepulturas 2 e 3.

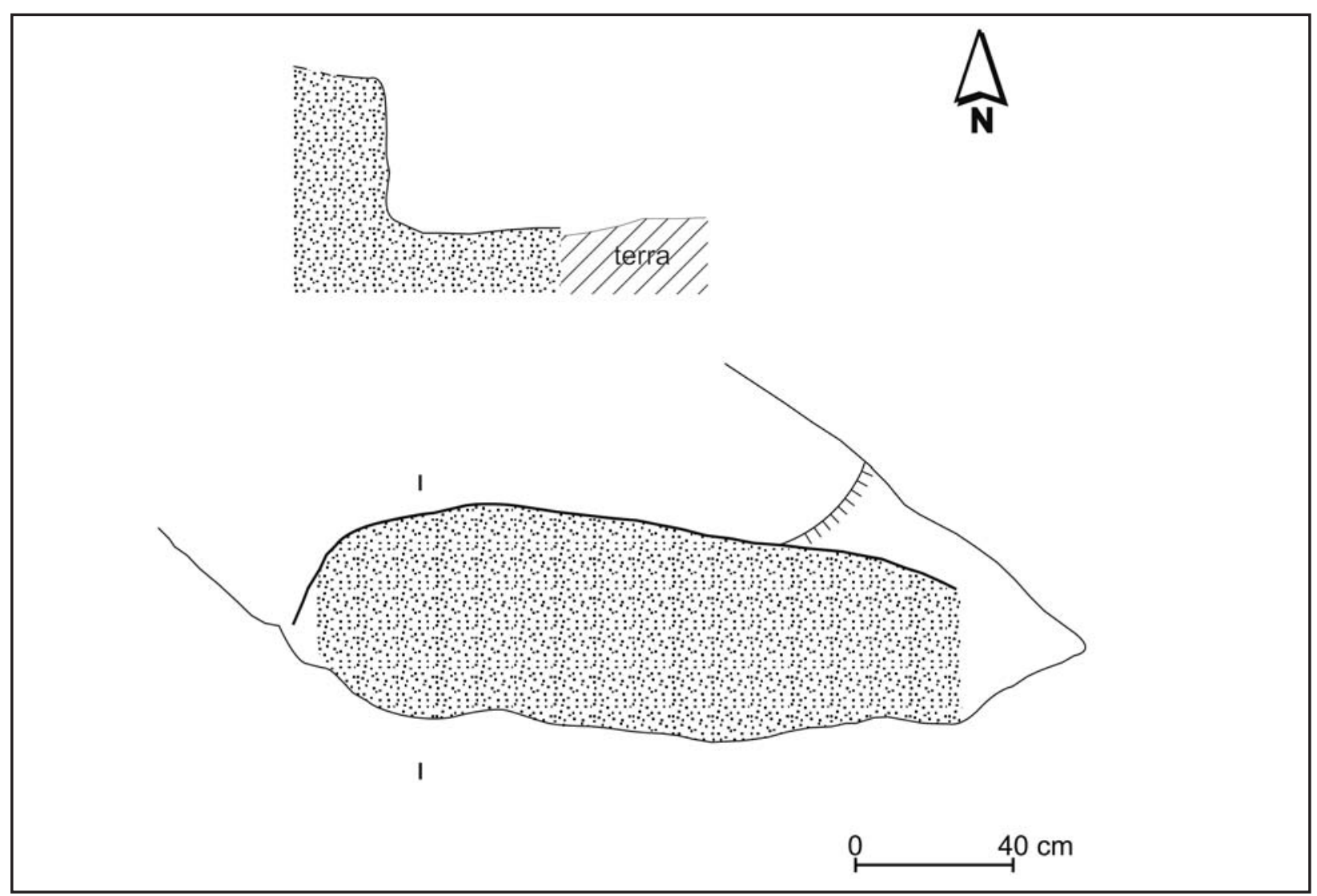

Fig. 15: Desenho da Sepultura Escoiral 1. 


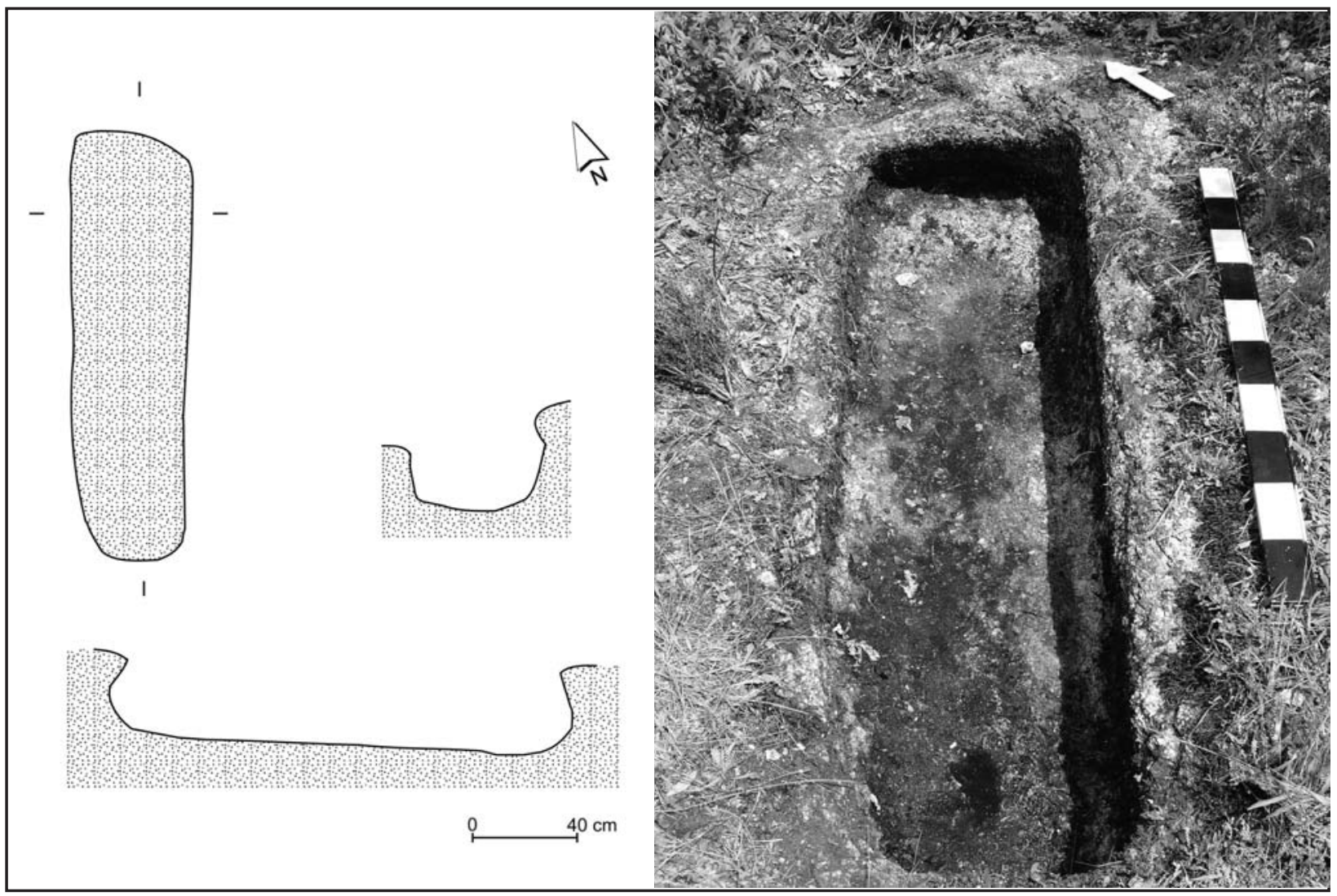

Fig. 16: Desenho e fotografia da Sepultura Escoiral 2.

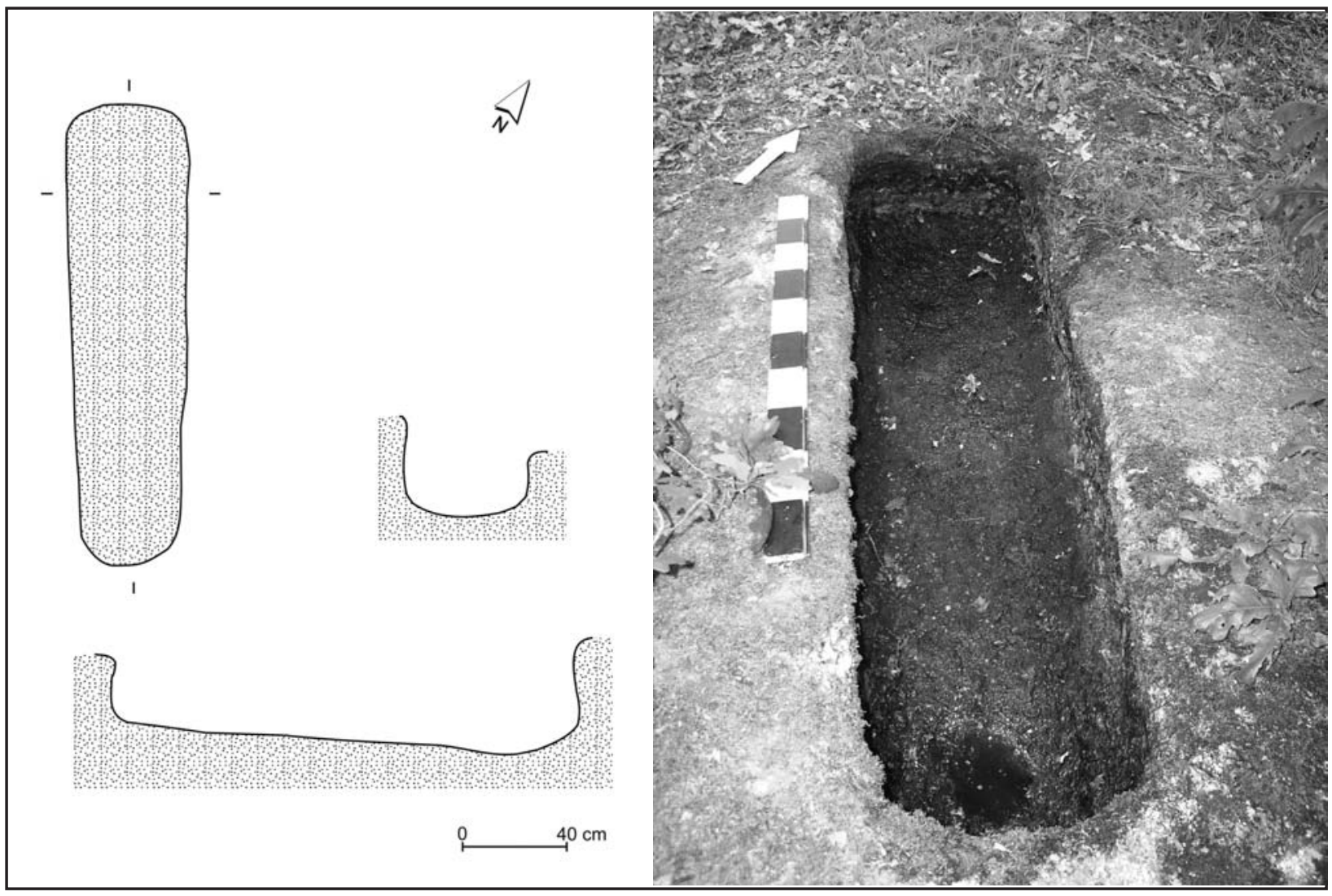

Fig. 17: Desenho e fotografia da Sepultura Escoiral 3. 
O próprio topónimo por que é conhecida a área, 'Escoiral' (que abrange um pinhal e várias terras de cultivo), por si só seria indicador arqueológico e, efectivamente, corresponde à existência de grande quantidade de escória, atingindo por vezes grande concentração.

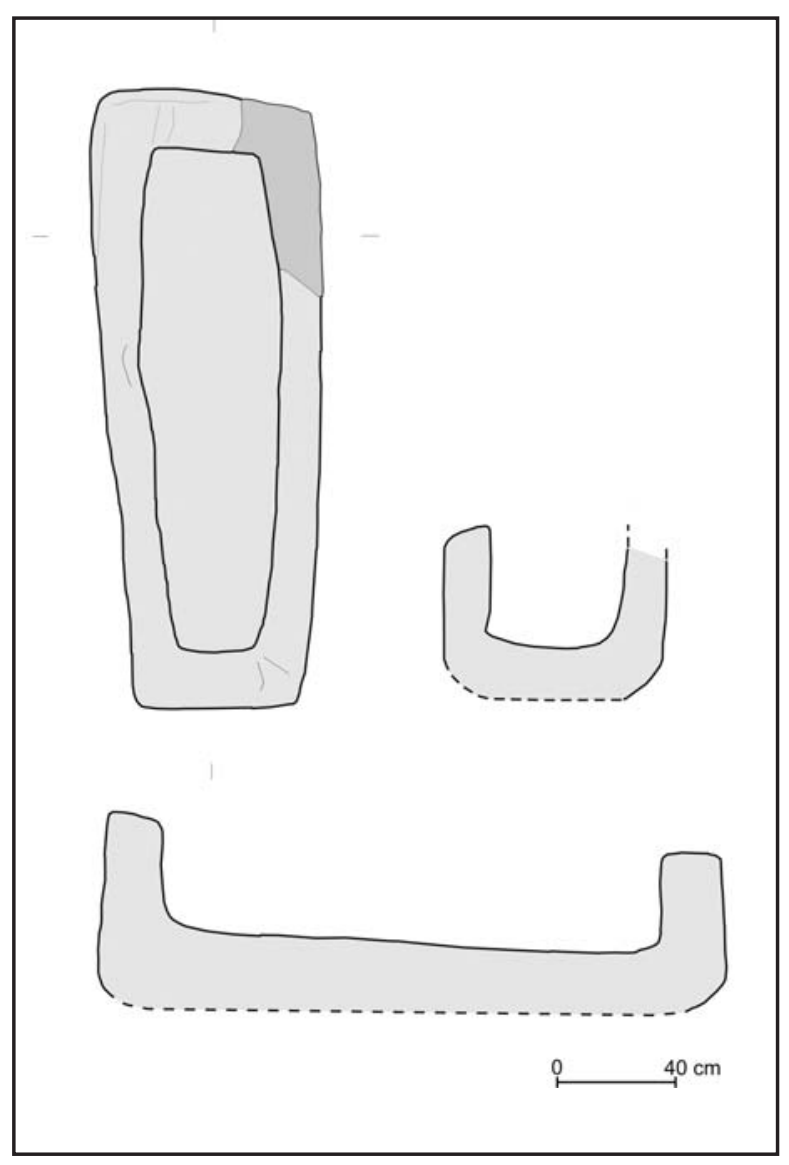

Quanto aos materiais cerâmicos, hoje são raros e incaracterísticos, mas quando se efectuaram surribas para plantar vinha terão aparecido grandes quantidades de "cerâmica vermelha, possivelmente restos de tejoleiras (sic), de tégulas e loiça" e "duas mós manuais dormentes" (Lusitano, 1991, p. 117, 172). Também houve várias pessoas que nos referiram que há cerca de cinquenta anos, também por ocasião de preparação dos terrenos para plantar vinha, terão aparecido estruturas de granito e "tijolo" e "grandes caixas de pedra" que foram destruídas após uma busca infrutífera de objectos valiosos. Assinala-se a presença de mais vestígios de superfície na encosta voltada a sudeste (no mapa da Fig. 13 com o número 7), fragmentos de tegulae e de cerâmica comum aparecem nas terras revolvidas.

Estes vestígios dizem-nos que as duas sepulturas do Outeiro do Vale não estão isoladas. Por um lado, permaneceu a tradição de sepultar naquela área, de que são testemunho as sepulturas rupestres e o sarcófago, por outro, o habitat a que corresponderão estes vestígios funerários desenvolver-se-ia mais abaixo na encosta. Também não é de estranhar que as sepulturas rupestres se encontrem mais próximas destes vestígios de povoamento ${ }^{10}$, uma vez que sabemos que ao longo da Alta Idade Média se foi esquecendo o preceito antigo de afastar os mortos do mundo dos vivos.

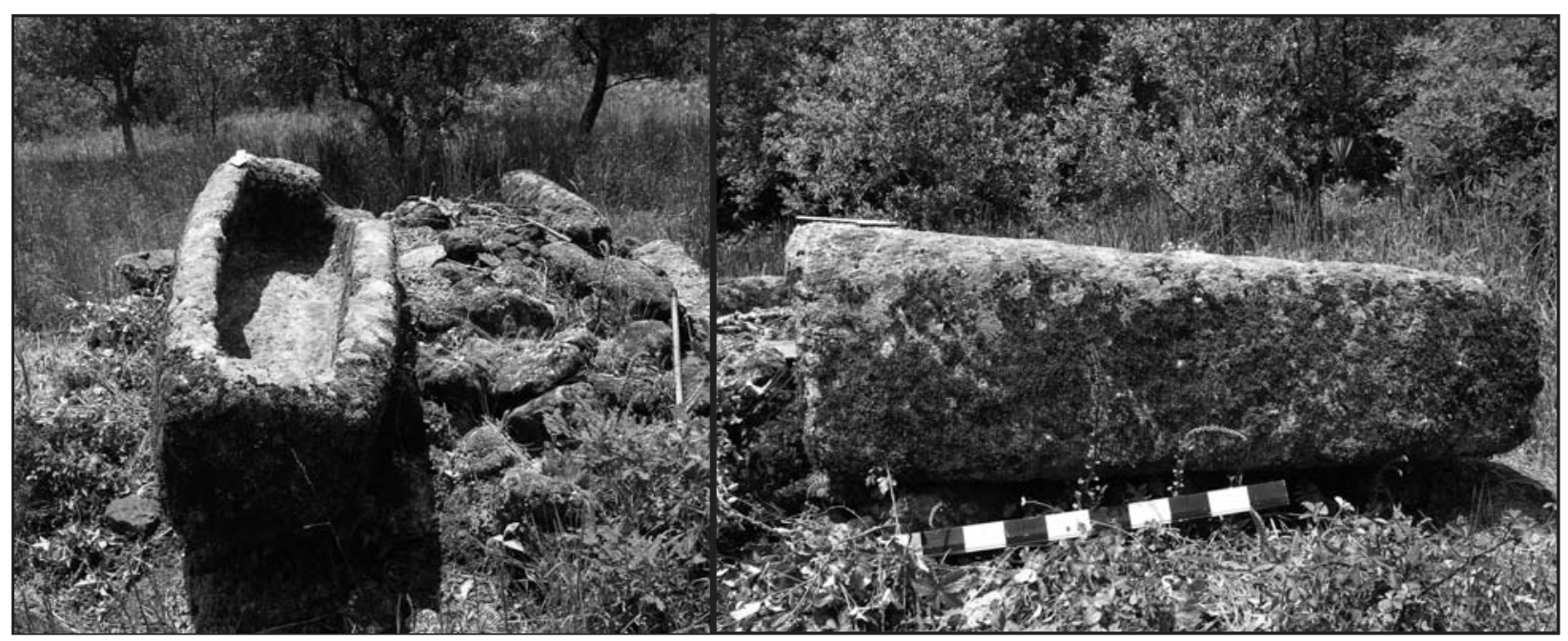

Fig. 18: Sarcófago do Escoiral, desenho, actual localização e aspecto do perfil.

${ }^{10}$ Claro que é um apenas um pressuposto que a área tenha continuado a ser ocupada em momento contemporâneo dos sepulcros escavados na rocha. 
Embora um pouco mais longe, pensamos que é interessante constatar a existência de vestígios de um cemitério mais recente. $\mathrm{Na}$ 'Quinta do Passal' (vide mapa da Fig. 13) guardavam-se, até há uns anos, "três estelas funerárias medievais, duas circulares e uma quadrada. Têm cruz de um lado e do outro." "11 Apesar de não nos ter sido possível a sua observação, pois o actual dono da quinta ofereceu-as a um particular, podemos dizer que estas estelas estão em conformidade com o topónimo 'Passal' e com a tradição de que ali existiu um cemitério onde vinham a enterrar os defuntos de toda a actual freguesia, bem como da povoação de Queiriga (vide mapa da Fig. 2). Segundo a mesma tradição, ali teria sido a antiga Côta, de onde veio o nome da freguesia ${ }^{12}$.

É possível que estes vestígios correspondam ao templo paroquial mais antigo da freguesia (até porque, segundo dizem, os assentos paroquiais estavam guardados na Quinta do Passal até aos princípios do século XX).

Também essencial para contextualizar estes achados é a existência de um eixo viário que poderá remontar à época romana (localmente apelidado 'estrada romana') ${ }^{13}$, que passa precisamente a meia encosta, não longe das sepulturas escavadas na rocha, por caminhos assinalados com cruzes gravadas em penedos, passando por um cruzamento conhecido como "Quatro Caminhos" (n. 6 no mapa da Fig. 13). Talvez daqui seguisse um trajecto para norte, que demandaria Fráguas ${ }^{14}$, passando perto de outras estações que terão ocupação romana e alto medieval ${ }^{15}$. Para sul dirige-se para o rio, que seria cruzado onde existe uma ponte medieval com um elegante arco quebrado (conhecida como 'ponte

${ }^{11} \mathrm{Vaz}, 1997$, p. 132. As estelas estariam guardadas junto da actual capela, dedicada a St. ${ }^{\circ}$ António, um edifício religioso reerguido há umas décadas como templo particular, mas foi nos terrenos adjacentes que apareceram ossadas e outros vestígios de sepulcros.

${ }^{12}$ As localidades actuais têm a designação "de Côta", como Nogueira de Côta e Sanguinhedo de Côta.

13 No mapa da Fig. 13 foi parcialmente reconstituído o traçado viário que a memória popular conservou como antigo, sendo o eixo norte sul aquele que é considerado 'romano'. A descida até ao rio é relativamente íngreme, pelo que se justifica o trajecto serpenteante. É muito provável que remonte à utilização da ponte gótica sobre o rio Vouga, não sendo descabido que exista uma tradição anterior. Também nos disseram que, ligeiramente a montante, perto da quinta assinalada na Carta Militar de Portugal como 'Quinta do Saltadoiro' (na margem esquerda), existiam poldras que eram usadas para romana'). Pelo que pudemos observar a silharia é toda muito uniforme e não parece ter siglas. A zona do tabuleiro encontra-se muito degradada e a ponte ameaça ruir. Segundo I. Vaz, este eixo viário ligaria a Viseu por trajecto não muito distante da antiga estrada nacional que liga esta cidade a Vila Nova de Paiva e, de Côta, iria a Queiriga (Vaz, 1997, p. 383). Esta informação parece ser corroborada pela tradição local, que recorda um antigo caminho de Queiriga por onde passariam com os defuntos que vinham a enterrar na Quinta do Passal.

\subsection{Contextualização regional}

São conhecidas na região de Viseu outras sepulturas construídas com tégulas, infelizmente as notícias que temos da sua existência são episódicas e não correspondem a nenhuma escavação cientificamente conduzida ${ }^{16}$.

$\mathrm{O}$ maior número de referências diz respeito à sede da antiga civitas de Viseu. Na igreja de S. Miguel (CNS 2666) existiria uma concentração de sepulturas de inumação, descritas por José Coelho, entre as quais se contam várias construídas com elementos avulsos, provavelmente reutilizações, de "tejolos" e de "telhas (tegula e imbrex)", existindo ainda dois sarcófagos, um de mármore e outro de granito ${ }^{17}$. Uma sondagem de emergência em 1983 levou à identificação de duas sepulturas de inumação constituídas por tegulae, a que se conservava na totalidade era de secção quadrada e planta trapezoidal, mas o fundo de saibro não se encontrava revestido (Vaz, 1997, p. 356, est. CLVI). A existência de epígrafes funerárias

atravessar o rio, o que significa que há vários sítios onde é possível transpôr o Vouga.

${ }^{14}$ Esta povoação tem uma série de estações de época Romana e Alto Medieval (CNS: 11817, 14771, 14775, 14783, 22172, 14779). O próprio topónimo estará relacionado com a actividade de transformação do ferro, documentada por extensas áreas de escorial (Vieira, 2004, p. 33-34, 42, 51, 136-139). A proximidade com a via e o tipo de vestígios têm paralelismo com a área em estudo.

${ }^{15}$ Como Franqueira, em Sanguinhedo de Côta, CNS 22023.

${ }^{16}$ Este panorama, aliás, estende-se um pouco a todo o território nacional, sendo as necrópoles de contexto rural as mais desconhecidas. Mesmo em Mértola, onde as três necrópoles urbanas foram escavadas e apresentam dos melhores conjuntos estudados, das rurais praticamente não se sabe nada (Lopes, 2003, p. 159-165).

17José Coelho, citado por Vaz (1997, p. 355). 


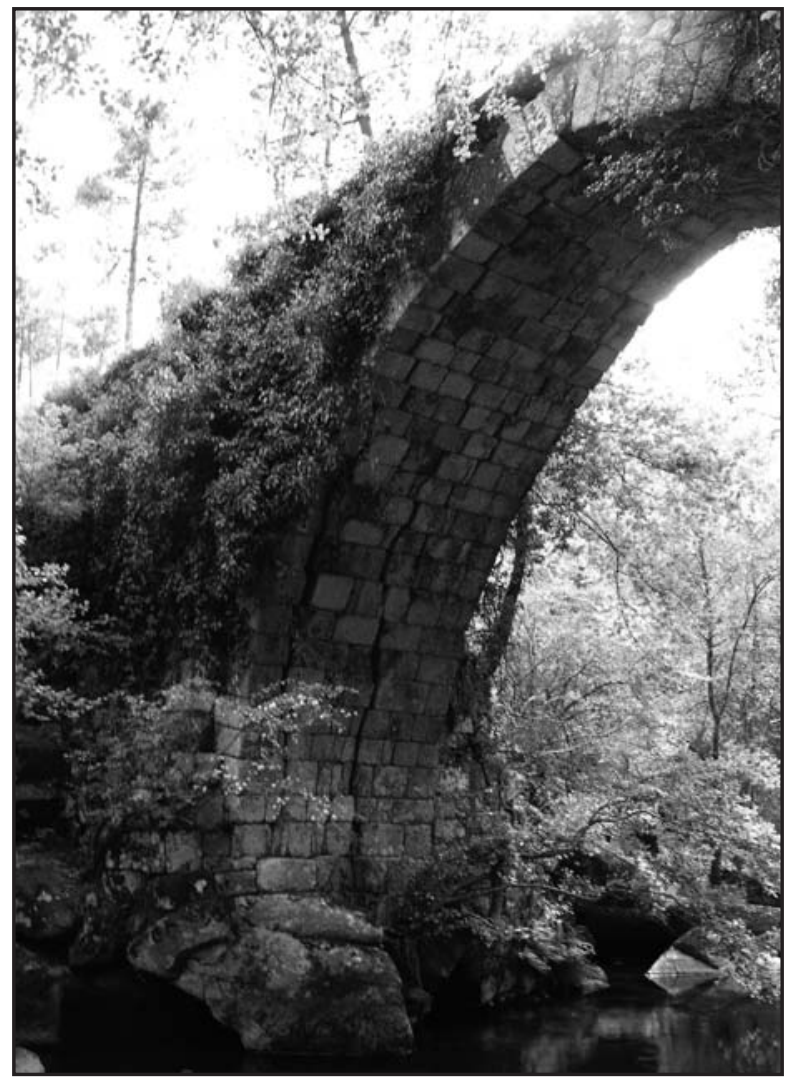

Fig. 19: Ponte sobre o Vouga. Vista da margem direita, a montante.

romanas e a localização junto de um importante eixo viário, apontam para um fenómeno de continuidade desta área sepulcral, sendo credível que em determinado momento tenha sido erguido um templo cristão precursor do actual dedicado a S. Miguel. Nas proximidades, José coelho identificou três sepulturas antropomórficas "cavadas em saibro duro", nos alicerces da sua casa da Via Sacra (Marques, 2000, p. 158-159). Temos, portanto, uma necrópole extra muros que apresenta uma diacronia interessante, associada a diferentes tipologias de sepulturas.

Ainda em Viseu, na Avenida Emídio Navarro (CNS 3486), foram encontrados vestígios de outra necrópole com sepulturas de inumação. Tal como a anterior, situa-se junto de um eixo viário e terá uma fase mais antiga, neste caso documentando-se incinerações. A outro momento corresponderão sepulturas feitas com tegulae, formando um telhado de duas águas, sendo os topos encerrados também com o mesmo material (uma, que deveria ser de criança, encontra-se no Museu da Assembleia Distrital de Viseu), mas também existiriam outras de secção quadrangular e, do mesmo formato, com lajes (Vaz, 1997, p. 356), o que se aproxima do nosso caso de estudo.
Uma terceira necrópole, no sítio conhecido como 'Cerrado' (CNS 1581), demonstra a mesma aparente continuidade. Sabe-se da existência de um sarcófago, coberto com uma epígrafe funerária romana reutilizada, e de sepulturas de tégulas com secção triangular. Existia ali uma capela de St. ${ }^{\circ}$ Amaro, em cujo edifício terão sido reutilizados materiais de época romana (Vaz, 1997, p. 357). Tal como nos dois sítios anteriores, estamos perante uma necrópole extra muros que assistiu a uma continuidade na tradição como local de enterramento, tendo atraído a fundação de uma capela.

Para se ter uma ideia de quão magros são os dados que possuímos, estas necrópoles urbanas são dos melhores exemplos em termos de descrição dos vestígios. Passemos agora aos sítios do mundo rural.

No local conhecido como 'Assento do Turco' (S. Pedro de France, Viseu), foram recolhidas tegulae que faziam parte de uma "pequena sepultura, pavimentada e forrada de tégulas romanas, tendo uma delas a letra $\mathrm{P}$ e fragmentos de cerâmica. Perto, encontra-se outra, de blocos de granito, cortada ao meio pelo caminho. A poucos metros daí, há sepulturas sobre algumas grandes rochas." (Cunha, 1968, p. 11). Desconhece-se a morfologia das sepulturas, contudo, será uma estação onde estão presentes diferentes tipos de sepulcros, um pouco como no Outeiro do Vale: de tégulas, de lajes graníticas e rupestres. O mesmo local terá atraído inumações de períodos distintos, mas desconhecemos se existem vestígios de um habitat próximo.

Na estação de 'Alto da Costa' (Germinade, S. Pedro do Sul, Viseu, CNS 1334) terá existido uma necrópole, da qual se conhecem duas inscrições funerárias romanas (Vaz, 1997, p. 83; 228-229; 265-266). Amorim Girão dá-nos notícia deste achado em 1924, trata-se de um conjunto de sete sepulturas "grosseiramente rectangulares", "três delas construídas de pedra e quatro feitas de grossos telhões de rebôrdo". Pela imagem que publica (apesar de já só ter observado quatro sepulturas, pois as outras tinham sido destruídas), é possível perceber que cinco destas sepulturas, uma de lajes graníticas e quatro de tegulae apresentam orientação grosso modo Oeste-Este, enquanto que as restantes duas, estruturadas com pedras, teriam orientação NNO-SSE. As inscrições funerárias romanas estavam reutilizadas nestas sepulturas, uma delas na 
cobertura. As sepulturas de pedra "constam dum rectângulo de pedras mais ou menos aparelhadas, assentes directamente sôbre o saibro rijo, e cobertas por outras pedras dispostas no sentido da sua menor dimensão", enquanto que as restantes "formam uma espécie de caixas rectangulares engenhosamente feitas de telhas romanas de rebôrdo (tegulae)" (Girão, 1924, p. 249). Aqui estão presentes também vários períodos, um documentado pelas inscrições e outro(s) a que correspondem as sepulturas de elementos avulsos. Mais uma vez encontramos a associação de sepulcros de tegulae com outros de lajes. É curioso que dois destes últimos exemplares não apresentem orientação Oeste-Este.

Em Vilar d'Ordem (Povolide, Viseu), no local conhecido como 'Quinta', terão existido "sepulturas feitas de «pedras e telhas», de forma rectangular” (Vaz, 1997, p. 142).

Estes exemplos mostram que as sepulturas do Outeiro do Vale não são um caso isolado, mas também não ajudam a interpretá-las. As necrópoles de Viseu, em contexto urbano, mostram como houve uma passagem dos rituais de incineração para as sepulturas de inumação, sem que tivesse havido um corte com os locais de enterramento já utilizados ${ }^{18}$ e essa continuidade prossegue com a cristianização (como sugerem as capelas aí construídas). Os três exemplos em contexto rural apresentam uma evolução diferente, pois nenhum se encontra próximo de um templo actual. O que aproxima todas estas necrópoles é a aparente diacronia e os materiais empregues, as tegulae e as lajes de pedra, sendo maioritárias as referências (quando existem) a plantas rectangulares e secções quadrangulares.

\section{NOTAS INTERPRETATIVAS}

No momento de procurar fazer uma aproximação tipo-cronológica estamos perante

${ }^{18}$ Esta situação será semelhante à diagnosticada nas necrópoles conhecidas de Braga, admitindo-se aí uma perduração até ao século VI/VII (Martins e Delgado, 1989-90, p 175-178).

${ }^{19}$ A propósito da realidade na Gália e Germânia, entre os séculos V e VIII, Dierkens e Périn (1997, p. 81) criticam a forma como por vezes os arqueólogos atribuem sepulcros ao credo cristão com base nestas três características.

${ }^{20}$ Por outro lado é sabido que os antigos hábitos pagãos não desapareceram de imediato, pelo contrário, em muitos casos vão ser assimilados à nova crença, o que poderá dificultar a uma série de limitações. À impossibilidade de obter a segurança de uma datação absoluta somase a ausência de espólio e a inexistência de estudos regionais. Apesar destas limitações, pensamos que não devemos deixar de tentar uma aproximação interpretativa, mesmo que provisória. Resta-nos assim a análise da tipologia específica de cada sepultura e as características da sua implantação.

A questão tipo-cronológica arrasta consigo o problema cultural: estaremos perante tumulações cristãs? As três características que vulgarmente são associadas a túmulos cristãos estão presentes: inumação, por oposição à cremação; orientação Oeste-Este; abandono da prática de colocar oferendas no interior da tumulação. Porém, é necessário frisar que não temos elementos que apontem inequivocamente a prática da religião cristã $^{19}$.

O problema que se coloca em primeiro lugar é que duas destas características são diagnosticadas em função de um uso anterior que se altera a determinado passo. Ora, desconhecemos para a região os usos funerários pagãos, tanto romanos como anteriores, ou seja, não sabemos a que ponto as populações utilizaram o costume romano, nem quais eram os costumes vigentes no período precedente ${ }^{20}$.

Outra questão que não se pode olvidar é que, até época bastante tardia, não existiram disposições concretas ditadas pela igreja no que diz respeito aos rituais de enterramento, embora algumas práticas fossem repudiadas nos concílios (como por exemplo a oferta de alimentos e os enterramentos no interior dos templos) ${ }^{21}$. Havia, portanto, uma certa liberdade no acto de enterramento, que era uma cerimónia de cariz particular (Barroca, 1987, p. 38) e não litúrgica como o será mais adiante. análise do registo arqueológico (Sales, 2003, p. 332; Barroca, 1987, 37-38 ). Neste nosso caso, a maior dificuldade reside na falta de dados. São conhecidos pontualmente achados de estelas funerárias romanas, mesmo em contexto rural, mas aparecem descontextualizados. Para o período pré-romano, não há qualquer indicador do ritual praticado.

${ }^{21}$ Como acontece, por exemplo, no I e II Concílios de Braga $(561,572)$, cfr. textos dos concílios na obra editada por José Vives (1963). 
A orientação Oeste-Este, com a cabeça para Poente, significa que o "defunto ficaria assim a olhar para Oriente, conforme a Igreja recomendava para o enterramento cristão" (Barroca, 1987, p. 123). Todavia, esta recomendação é tardia, podendo tratar-se da assimilação de uma prática que era corrente, talvez com origem em remotos cultos solares ${ }^{22}$. A verdade é que foi assimilada pelos cristãos primitivos.

A orientação das sepulturas em análise é OesteEste - sepultura 1: $260^{\circ}$, sepultura 2: $255^{\circ}-$, com apenas $5^{\circ}$ de diferença entre cada uma. Quando não existia um edifício a apontar o alinhamento seria natural que a observação do nascer do sol indicasse a posição correcta, pelo que se pode esperar uma variabilidade até $40^{\circ}$, respeitante à observação do astro nas diferentes épocas do $\mathrm{nno}^{23}$.

A inumação começa a ser frequente no final do Império romano, particularmente a partir do século III, e costuma estar associada à divulgação de cultos orientais, entre os quais se encontra, também, o cristianismo (Dierkens e Périn, 1997, p. 81). Contudo, numa zona rural e setentrional da Lusitânia é de estranhar que outro culto oriental justifique a opção pela inumação, é menos rebuscado pensar numa penetração do cristianismo quando este deixa de ser perseguido (com o Édito de Milão), mas sobretudo a partir do momento em que este se torna a religião oficial do império em $380^{24}$.

À ausência de mobiliário fúnebre interliga-se o anonimato do sepulcro, uma vez que o cristianismo desvaloriza o que o indivíduo foi em

${ }^{22}$ Como refere Katja Kliemann, a orientação Oeste-Este não é exclusiva do mundo cristão e já se dá em tempos pré-históricos. O culto solar é uma das hipóteses a ter em conta ao analisar a origem desta prática (Kliemann, 1987, p. 497498).

${ }^{23}$ Ver o estudo da necrópole de Esquerda (Catalunha) de Imma Ollich (1982). Também o pequeno texto de Katja Kliemann (1987), já referido, aponta para a aplicação desta observação para se conhecer a época do ano em que foram feitos os enterramentos e, apesar de ser céptica quanto aos resultados, indica bibliografia.

${ }^{24}$ No contexto do noroeste peninsular, Carlos Alberto Ferreira de Almeida acredita que a romanização tardia terá favorecido a penetração do cristianismo, nos meados e final do século IV e escreve: "É bem sintomático que em toda a România seja esta a única zona a designar os dias da semana, não à romana, mas de maneira cristã" (Almeida, 1973, p. 14-15). Esta nossa área não pertence à região que o autor refere, mas não deixa de ter algumas afinidades, não esqueçamos que a vida, pois isso não será importante para a salvação no momento da Ressurreição. Estas duas características iniciam-se por volta do século II, generalizando-se no século $\mathrm{V}^{25}$.

A inexistência de uma tipo-cronologia portuguesa leva-nos a fazer comparações alémfronteiras, embora com toda a cautela a que obrigam os muitos quilómetros que separam os diferentes territórios e as diferenças culturais entre eles.

Com base numa investigação volumosa, alguns autores franceses apresentaram uma interessante proposta tipo-cronológica para as sepulturas do Baixo Império à Idade Média no Sudeste da Gália. Nesse quadro, a nossa sepultura 1 entraria no grupo do 'tipo 5' ("coffrages de section quadrangulaire en tuiles") ${ }^{26}$. Este conhece o seu pleno desenvolvimento nos séculos IV e V naquela região, num caso (em Sézegnin) aparece simultaneamente com a alteração para uma orientação Oeste-Este (datada entre 350 e 400). Parece declinar ainda no século $\mathrm{V}$, embora perdure durante toda a centúria; nesta fase final parece ter tendência para se tornar trapezoidal (Colardelle, 1996, p. 277). Curiosamente, não encontramos neste estudo um paralelo para a nossa sepultura 2, uma vez que o grupo das sepulturas compostas por lajes tem como principal característica uma certa antropomorfização.

Para a área catalã existem alguns tentames de sistematização, apesar de os autores sentirem a necessidade de estudos sistemáticos ${ }^{27}$. Uma hipótese interpretativa para as sepulturas de

fronteira com a Gallaecia não se encontrava longe.

25 Apesar desta tendência geral, em Mértola, na necrópole da Achada de S. Sebastião que perdurará até ao século V e na necrópole do Rossio do Carmo, que a partir deste século parece substituir a anterior, vê-se como costumes anteriores tardam em desaparecer, neste caso numa comunidade de tipo urbano e até letrada como mostram os epitáfios (Lopes, 1999; Torres e Macias, 1993). Esta situação aponta para uma cronologia mais avançada para as nossas sepulturas.

${ }^{26}$ Cfr. descrição das páginas 276-278 e quadros 1 e 2 em Colardelle et al., 1996.

${ }^{27}$ Por exemplo, Bosch e Vallès (1987, p. 337) concluem que os dados que possuem são parcelares, por um lado devido a acções destrutivas/saque e, por outro, devido à maioria dos dados serem provenientes de escavações antigas, mal realizadas/registadas. Jordina Sales propõe um esquema teórico, embora saiba que não encontra dados que suportem a totalidade do proposto devido à falta de estudos sistemáticos (Sales, 1996-97, p. 1275). 
lajes e/ou tegulae é avançada por Josep María Bosch e Jordi Vallès (1987). Neste trabalho, apontam para uma variação da cronologia em função de uma maior ou menor romanização: nas áreas mais romanizadas estas sepulturas surgiriam pelo século IV, em ambiente urbano, e no século $\mathrm{V}$ no rural, enquanto que apenas a partir do século VI-VII nas restantes áreas. Em ambiente rural, relacionam este tipo de sepulturas com o habitat disperso (Bosch e Vallès, 1987, p. 329-330). Um aspecto estatístico interessante é que a maioria destas sepulturas se encontram orientadas Oeste-Este, atribuindo-se os desvios às condições do terreno (Bosch e Vallès, 1987, p. 337).

Parece-nos, contudo, que a análise conjunta das sepulturas de lajes e/ou tegulae não engloba toda a complexidade que o registo encerra, aspecto que é tido em conta por Jordina Sales, que considera as sepulturas de lajes um fenómeno mais alargado no tempo, que é contemporâneo de outras soluções que têm uma menor duração, como é o caso das sepulturas feitas exclusivamente com tegulae, que considera o tipo mais antigo:

El que sí sembla clar (...) és que, en l'etapa cronològica intermèdia durant la qual les tegulae van perdent importància -enfront de la potenciació progressiva de les tombes excavades a la roca-, tenim les tombes de llosa que sembla que es mantenen en importància des que es comencen a documentar al segle IV fina a la seva progressiva desaparició ja a la Baixa Edat Mitjana. Bona prova d'això és que les trobem associades amb tombes de tegulae, per un cantó, i amb tombes excavades a la roca, per un altre (Sales, 1996-97, p. 1276 e esquema p. 1275).

Esta breve incursão por outras paragens mostra-nos que existem situações que poderão ter paralelo no nosso território e que poderão ser usadas como hipóteses de trabalho, ressalvadas as devidas distâncias. Assim, colocaríamos alguns aspectos em destaque: a questão da maior antiguidade das sepulturas de tegulae, situação

\footnotetext{
${ }^{28}$ É de notar que as grandes conclusões deste texto, escrito em 1987, ainda estão actualizadas, não só por ser um trabalho profundo e fruto de reflexão aturada, mas também porque os
}

que é apoiada por datações absolutas no caso francês e pelo uso deste tipo em contextos urbanos Baixo Imperiais; as plantas rectangulares são consideradas mais antigas que as trapezoidais; a utilização de sepulturas de tegulae e lajes em contexto rural apresentando padrão de povoamento disperso.

$\mathrm{Na}$ sequência do exposto, e voltando ao nosso território, pensamos que é acertada a designação de "necrópoles de transição" para o tipo de sepulcros que aqui consideramos, na definição que Mário Barroca propôs para o Entre-Douro-e-Minho ${ }^{28}$, que transcrevemos com a devida vénia:

Cemitérios de inumação constituídos por sepulturas elaboradas com materiais de tradição romana - tegula e tijolo - que adoptam a configuração rectangular ou, maioritariamente, trapezoidal. Em todas elas, e como denominador comum, regista-se a ausência de espólio votivo, o que parece apontar para uma cronologia bastante tardia. (...) É bem possível que pertençam a esse período de transição entre a Romanidade tardia e os alvores da Alta Idade Média, podendo-se incluir dentro da família paleocristã. (...) A sua ocorrência vai esmorecendo à medida que o tempo avança, até deixarem de estar presentes num momento ainda mal caracterizado, mas que deverá situar-se nos fins do século VI ou inícios do século VII. (1987, p. 59).

Em suma, as sepulturas de Outeiro do Vale poderão indiciar a existência de uma necrópole "de transição", talvez de ritual cristão. A proximidade de uma via e a distância relativamente à área que apresenta vestígios de habitat, aponta para a sua localização na periferia do mundo dos vivos, dentro da lógica prevalecente na Antiguidade. Os sepulcros rupestres e o sarcófago serão talvez indicadores de continuidade de ocupação, pelo menos parece ter persistido o uso do local com finalidade funerária. Contudo, não há tradição da existência de um templo, o que não quer dizer que não

nossos conhecimentos praticamente não progrediram deste então, mesmo com a descoberta de mais necrópoles a questão cronológica continua em aberto. 
existisse $^{29}$. Os vestígios que se seguem em termos cronológicos são as estelas funerárias, a quase 1 km de distância (dos sepulcros rupestres), possivelmente equacionáveis com a reorganização do espaço que se faz no momento da implantação da rede paroquial ${ }^{30}$.

\section{Considerações finais}

Muitas vezes tida como monótona e aportadora de poucos dados, a escavação de necrópoles tardo antigas e alto medievais é feita sobretudo em contextos de arqueologia de salvamento ou quando se remodelam espaços relacionados com templos urbanos (muitas vezes ocorre quando já houve uma destruição muito considerável dos vestígios, ou então incide apenas nas áreas a afectar pelas obras que precedem), sendo raramente objecto de projectos de investigação. Há honrosas excepções um pouco por todo o país, mas para a região em que está inserida esta estação não existem estudos sistemáticos. De uma forma geral, o que temos são dados muito parcelares e episódicos, que, embora importantes, não resultam da colocação de questões específicas a estes espaços e portanto subsistem muitas questões por resolver.

Pelo que ficou exposto é óbvia a necessidade de mais estudos monográficos que incidam sobre necrópoles de âmbito rural desde a Antiguidade Tardia à Idade Média, sob pena de não ser possível passar das conjecturas para caracterizar os usos funerários destes períodos. O sítio de Outeiro do Vale poderá ser um local interessante para futura investigação. Apesar de alguma destruição (como aquela que terá levado a exumar o sarcófago) é possível que o sítio se encontre relativamente bem conservado e sobretudo existem vestígios funerários e habitacionais que apresentam potencial para constituir um corpo de informação relevante.

\section{Agradecimentos}

Gostaríamos de deixar aqui expresso o nosso reconhecimento ao Presidente da Junta de

\footnotetext{
${ }^{29}$ Jordina Sales, no contexto da Catalunha, diz que os templos começam a ser indissociáveis das necrópoles a partir do século $\mathrm{V}$, situação que parece generalizar-se nos séculos VI e VII. Apesar de no nosso território não termos informação que permita confirmar ou desmentir esta hipótese, é de reter
}

Freguesia de Côta, Sr. Joaquim Polónio Lopes e aos proprietários do terreno onde se efectuaram as escavações, Sr. Joaquim Marques da Silva e esposa. Temos que referir a preciosa ajuda, nas escavações e prospecções, do João Carlos Teixeira e o apoio da Fátima Beja e Costa e da Ana Barradas. Também à Mafalda Alves e ao Victor Dias aqui deixamos o nosso agradecimento.

\section{Bibliografia}

ALMEIDA, C. A. F. de (1973) - Notas sobre a Alta Idade Média no Noroeste de Portugal. Sep. Revista da Faculdade de Letras. Série História. Porto. 3, p. 5-28.

BARROCA, M. J. (1987) - Necrópoles e sepulturas medievais de Entre-Douro-e-Minho (séculos $V$ a $X V)$. Porto. Provas ECDU apresentadas à Faculdade de Letras. Texto policopiado.

BOSCH I CASADEVALL, J. M.; VALLÈS I CUEVAS, J. (1987) - Sepultures tipus cista de lloses i/o «tegulae» a Catalunya: hipòtesi interpretativa (1). Actas do II Congreso de Arqueología Medieval Española: Comunicaciones. Madrid: Asociación Española de Arqueología Medieval. III, p. 327-338.

COLARDELLE, M.; DÉMIANS D'ARCHIMBAUD, G.; RAYNAUD, C. (1996) - Typo-chronologie des sépultures du Bas-Empire à la fin du MoyenÂge dans le Sud-Est de la Gaule. In GALINIÉ, H.; ZADORA-RIO, E., coords. - Archéologie du cimitière chrétien. Tours : $11^{\mathrm{e}}$ supplément à la Revue Archéologique du Centre de la France, p. 271-303.

CUNHA, P. e D. da (1968) - S. Pedro de France na lenda na tradição e na história: costumes $e$ superstições. Viseu.

DIERKENS, A.; PÉRIN, P. (1997) - Death and burial in Gaul and Germania, $4^{\text {th }}-8^{\text {th }}$ century. In WEBSTER, L.; BROWN, M. - The transformation of the roman world (AD 400-900). Londres: British Museum, p. 79-95. a ideia de que os templos possam ter tido uma arquitectura muito frágil, inclusivamente em madeira, não deixando traços facilmente detectáveis (Sales, 2003, 327-328.

30 A exemplo da evolução detectada para o Entre-Douro-eMinho a partir do século X (López, 2004). 
GIRÃO, A. de A. (1924) - Necrópole Romana de Germinade (S. Pedro do Sul). O Archeologo Português. Lisboa: Imprensa Nacional. 26, p. 249-251.

KLIEMANN, K. (1987) - La orientación de las sepulturas medievales. Actas do II Congreso de Arqueología Medieval Española: Comunicaciones. Madrid: Asociación Española de Arqueología Medieval. III, p. 495-500.

LOPES, Virgílio A. M. (D.L.1999) - A necrópole da Achada de S. Sebastião. In: A necrópole e a ermida da Achada de S. Sebastião. Mértola: Campo Arqueológico de Mértola, Escola Profissional Bento de Jesus Caraça, p. 79-99.

LOPES, Virgílio A. M. (2003) - Mértola na Antiguidade Tardia: a topografia histórica da cidade e do seu território nos alvores do cristianismo. Mértola: Campo Arqueológico de Mértola.

LÓPEZ QUIROGA, J. (2004) - El final de la Antigüedad en la Gallaecia: la transformación de las estructuras de poblamiento entre Miño y Duero (siglos $V-X$ ). A Coruña: Fundación Pedro Barrié de La Maza; Instituto de Estudios Gallegos 'Padre Sarmiento"-CSIC.

MARTINS, M.; DELGADO, M. (1989-90) - As necrópoles de Bracara Augusta: os dados arqueológicos. Cadernos de Arqueologia. Braga. 6-7, p. 41-186.

OLLICH I CASTANYER, I. (1982) - Tipologia de les tombes de la necropolis medieval de
l'Esquerda (Osona). In Necròpolis i sepultures medievals de Catalunya [Annex 1 de Acta Medicevalia]. Barcelona, p. 105-147.

SALES I CARBONELL, J. (1996-97) -El problema cronocultural de les necròpolis durant l'antiguitat tardana. Annals de l'Institut d'Estudis Gironins. (Homenatge al Dr. Pere de Palol/3). Girona. 38, p. 1265-1279.

SALES I CARBONELL, J. (2003) - Necrópolis cristianas tardoantiguas en el área catalana: estado de la cuestión. Acta Antiqua Complutensia III: Santos, obispos y reliquias. Alcalá de Henares, p. 319-333.

TORRES, C.; MACIAS, S. coords. (1993) - Museu de Mértola. Basílica paleocristã. Mértola: Campo Arqueológico de Mértola.

VAZ, J. L. I. (1997) - A Civitas de Viseu (Espaço e Sociedade). Coimbra: Comissão de Coordenação da Região Centro.

VIEIRA, M. A. (2004) - Alto Paiva. Povoamento nas épocas romana e alto medieval. Lisboa: Instituto Português de Arqueologia (Trabalhos de Arqueologia; 36).

VIEIRA, M. A. (2006) - Alguns aspectos do povoamento tardo antigo e alto medieval do curso superior do rio Paiva: as sepulturas escavadas na rocha. Conimbriga. Coimbra. 45, 311-335.

VIVES, J. ed. (1963) - Concílios visigóticos e hispano-romanos. Barcelona/Madrid: CSIC. 